OPEN ACCESS

Edited by:

Angel Borja,

Technological Center Expert in Marine and Food Innovation (AZTI), Spain

Reviewed by:

Lawrence A. Kapustka,

LK Consultancy, Canada

Tamara Yankovich,

International Atomic Energy Agency,

Austria

Carlos Rocha

Trinity College Dublin, Ireland

${ }^{*}$ Correspondence:

Peter Wolfgang Swarzenski

P.Swarzenski@iaea.org

${ }^{\dagger}$ Present address:

Roberta L. Hansman,

Woods Hole Oceanographic Institution, Woods Hole, MA,

United States

Specialty section:

This article was submitted to Marine Ecosystem Ecology,

a section of the journal

Frontiers in Marine Science

Received: 15 January 2020

Accepted: 11 May 2020

Published: 03 June 2020

Citation:

Cresswell T, Metian M, Fisher NS,

Charmasson S, Hansman RL,

Bam W, Bock C and Swarzenski PW

(2020) Exploring New Frontiers

in Marine Radioisotope Tracing -

Adapting to New Opportunities

and Challenges.

Front. Mar. Sci. 7:406.

doi: 10.3389/fmars.2020.00406

\section{Exploring New Frontiers in Marine Radioisotope Tracing - Adapting to New Opportunities and Challenges}

\author{
Tom Cresswell'1, Marc Metian², Nicholas S. Fisher ${ }^{3}$, Sabine Charmasson, \\ Roberta L. Hansman²+, Wokil Bam ${ }^{2,5}$, Christian Bock ${ }^{6}$ and Peter Wolfgang Swarzenski2*
}

'Australia's Nuclear Science and Technology Organisation, Lucas Heights, NSW, Australia, ${ }^{2}$ Radioecology Laboratory, International Atomic Energy Agency Environment Laboratories, Monaco, Monaco, ${ }^{3}$ School of Marine and Atmospheric Sciences, Stony Brook University, Stony Brook, NY, United States, ${ }^{4}$ Institut de Radioprotection et de Sûreté Nucléaire, PSE-ENV/SRTE Research Laboratory for Radionuclide Transfer in Aquatic Ecosystems, Saint-Paul-Lez-Durance, France, ${ }^{5}$ Department of Oceanography and Coastal Sciences, Louisiana State University, Baton Rouge, LA, United States, ${ }^{6}$ Integrative Ecophysiology, Alfred Wegener Institute Helmholtz Centre for Polar and Marine Research, Bremerhaven, Germany

Radioisotopes have been used in earth and environmental sciences for over 150 years and provide unique tools to study environmental processes in great detail from a cellular level through to an oceanic basin scale. These nuclear techniques have been employed to understand coastal and marine ecosystems via laboratory and field studies in terms of how aquatic organisms respond to environmental stressors, including temperature, $\mathrm{pH}$, nutrients, metals, organic anthropogenic contaminants, and biological toxins. Global marine issues, such as ocean warming, deoxygenation, plastic pollution, ocean acidification, increased duration, and intensity of toxic harmful algal blooms (HABs), and coastal contamination are all impacting marine environments, thereby imposing various environmental and economic risks. Being able to reliably assess the condition of coastal and marine ecosystems, and how they may respond to future disturbances, can provide vital information for society in the sustainable management of their marine environments. This paper summarizes the historical use of radiotracers in these systems, describes how existing techniques of radioecological tracing can be developed for specific current environmental issues and provides information on emerging issues that would benefit from current and new radiotracer methods. Current challenges with using radioecological tracers and opportunities are highlighted, as well as opportunities to maximize the application of these methods to greatly increase the ability of environmental managers to conduct evidence-based management of coastal and marine ecosystems.

Keywords: radionuclides, radiotracers, radioecology, ecosystem condition, marine, coastal

\section{INTRODUCTION}

Many of today's environmental challenges that threaten the health and viability of coastal and marine ecosystems are caused or heightened by a plethora of anthropogenic stressors that are exacerbated by a changing climate and ocean (Dwight et al., 2005). Global marine issues, such as ocean warming, deoxygenation, plastic pollution, ocean acidification, increased duration and 
intensity of toxic harmful algal blooms (HABs), and coastal contamination are all impacting marine environments, thereby imposing various environmental and economic risks (Turley and Gattuso, 2012; Speers et al., 2016; Yagi, 2016; Beaumont et al., 2019). Being able to reliably assess the condition of coastal and marine ecosystems, and how they may respond to future disturbances, can provide vital information for society in the sustainable management of their marine environments.

The use of a suite of radioactive isotopic tracers (radiotracers) both in controlled laboratory experiments (reviews by Fisher and Reinfelder, 1995; Fowler et al., 2004; Stewart et al., 2008; Metian et al., 2019a) and in field settings (Swarzenski and Porcelli, 2003; Fry, 2006; Baskaran, 2011; Fowler, 2011; Harmelin-Vivien et al., 2012) has been invaluable to advance our understanding of marine and coastal ecosystems. These experiments (lab and field) have enabled efficient analyses of the uptake and retention of diverse contaminants in aquatic organisms. The analysis of radioisotopes is rapid, relatively inexpensive, and enables experimentation with trace concentrations of elements, well below concentrations typical for most elements in natural waters. Consequently, this methodology has been useful to determine a contaminant's bioavailability (proportion of the total contaminant exposure that is available for uptake into biota), bioaccumulation (uptake of a contaminant into an organism from water and diet), bioconcentration (contaminant concentration in an organism relative to that in the ambient water), and, mostly for organic contaminants or organometallic compounds, biomagnification (in which the contaminant's concentration in the tissues of a predator exceed that in the tissues of its prey).

Nuclear techniques have opened up new perspectives on the pathways and rates of uptake (e.g., bioaccumulation) and biomagnification processes of radioactive and non-radioactive contaminants. Similarly, these techniques have been used for rapidly identifying and quantifying biochemical toxins in seafood, for assessing the impacts of sustained ocean acidification on diverse calcifying organisms, and for evaluating metabolic processes under increasing ocean temperature. Similarly, isotopes have allowed the reconstruction of the geochemical evolution of Earth have resulted in the temporal reconstruction of key environmental processes and rates.

The goal of this paper is to identify advantages that are conferred by using radioisotopes to address existing and emerging environmental processes in marine ecosystems. The paper is organized into four parts: (1) an introduction that reviews the historical use and success stories of radiotracers in coastal and marine science; (2) a section summarizing the development of existing techniques using radiotracers; (3) a section that identifies new tools and techniques that often are multidisciplinary, covering existing coastal and marine issues that would benefit from the use of radiotracers to assess ecosystem condition; and (4) a section describing the challenges and opportunities in this field going forward. The innovative use of radioisotopes in coastal and marine radioecology can help United Nations (UN) Member States work toward and achieve their respective UN Sustainable Development Goal (SDG) targets. The UN has further proclaimed $2021-2030$ as the Decade of
Ocean Science for Sustainable Development ${ }^{1}$ to promote global coordination and support for ocean science and the coastal communities that depend on a healthy and sustainable ocean. Radiotracers can be used in experimental and field applications to provide unique information and perspectives on how, for example, subtle changes to ocean chemistry over time may influence essential biological systems with far-reaching impacts.

\section{HISTORICAL USE OF RADIOTRACERS}

The exploration and use of radioisotopes in environmental science has advanced our understanding of natural processes. From developing a chronology of Earth's differentiation and planetary evolution using $\mathrm{Pb}$ isotope systematics (Patterson et al., 1955) to using products of legacy nuclear weapons testing to derive sedimentary age models, the utility of radioisotopes has evolved continuously over the last 60 years as analytical methods have been established and vastly improved. Indeed, the Suess effect, using radiocarbon $\left({ }^{14} \mathrm{C}\right)$ dendrochronology, became the cornerstone for supporting anthropogenic global warming and helped determine $\mathrm{CO}_{2}$ exchange rates between the atmosphere and oceans (Revelle and Suess, 1957), and was further developed into more contemporary (and not dependant on legacy atomic weapon testing) ${ }^{13} \mathrm{C}$ growth trend analysis in corals (Swart et al., 2010).

Radionuclides can be either natural or artificial and have been used to trace many processes in the marine sciences (see following examples). Indeed, radionuclides are characterized by their rate of radioactive decay, or loss that can be used as a clock to trace the rate of a variety of processes, making them powerful time pieces. Atmospheric nuclear weapons testing during 1945 to 1980 (peaking in 1963) and the development of civil use of nuclear energy has led to the release of many artificial radionuclides to the marine environment such as ${ }^{3} \mathrm{H},{ }^{90} \mathrm{Sr},{ }^{137} \mathrm{Cs}$, ${ }^{129} \mathrm{I}$ and ${ }^{238}, 239,{ }^{240} \mathrm{Pu}$ (Benitez-Nelson et al., 2018a). Almost at the same time, due to improvement in analytical chemistry and instrumentation, there was an increasing use of elements belonging to the classic three $\mathrm{U}-\mathrm{Th}$ series radioactive decay chains to investigate marine processes (Benitez-Nelson et al., 2018a). The GEOSECS (Geochemical Ocean Sections) program was one of the pioneering efforts to make use of radionuclides to study basin-scale processes (Broecker and Peng, 1982).

Natural and artificial fallout radionuclides have been used since the early 1970s for dating recent sediment and determining sedimentation rates (Robbins and Edgington, 1975; Appleby, 2008). In the 1960s and 1970s, numerous studies began to characterize the sorption of radionuclides to marine sediment and the bioaccumulation of radionuclides in aquatic biota; these in turn led to compilations of sediment partition coefficients (Kds) and bioconcentration factors (BCFs) of longlived radionuclides in marine sediments and organisms (IAEA, 2004). These Kds and BCFs have been used in modeling efforts to evaluate the cycling and potential impacts of radionuclides in marine ecosystems (European Commission, 1990; ICRP, 2008).

${ }^{1}$ http://oceandecade.org 
In addition, numerous studies explored the application of natural and artificial radionuclides to evaluate processes, such as: geochronology of sediment (e.g., Swarzenski et al., 2006; Appleby, 2008); contaminant uptake, retention and trophic transfer through organisms, including model predictions relative to results from independent field observations (e.g., Fisher et al., 1988, 2000; Roditi et al., 2000; Baines et al., 2002; Luoma and Rainbow, 2005; Baumann and Fisher, 2011); sediment plume dynamics (Swarzenski et al., 1995); carbon flux (Buesseler et al., 2006); water mass ventilation (Matsumoto and Key, 2004), GEOTRACES/GEOSECS/JGOFS programs (Broecker and Peng, 1982; Bowles and Livingston, 1997; Moffett and German, 2018); runoff; and groundwater discharges (Charette, 2001; Moore, 2006; Swarzenski, 2007; IAEA, 2010). Furthermore, by coupling radiotracers (e.g., ${ }^{222} \mathrm{Rn}$ and ${ }^{226} \mathrm{Ra}$ ) with stable isotopes of water (e.g., $\left.\delta^{18} \mathrm{O}\right)$, one can discriminate source terms of submarine groundwater discharge and distinguish fresh groundwater discharge from saline, recirculated groundwater. This information is vital for both groundwater resource managers that are tasked in developing potable water budgets as well as marine resource managers that are interested in the delivery of SGD-borne nutrients and contaminants to coastal ecosystems (Rocha et al., 2016).

\section{DEVELOPMENT OF EXISTING TECHNIQUES USING RADIOECOLOGICAL TRACERS}

The use of radioecological tracers helps in improving our understanding of contaminant transfer in marine organisms under various environmental conditions and also to better assess biogeochemical cycling of both organic and inorganic particles and dissolved species in a global change context. This section provides some specific examples of where radioecological tracers have been developed or can be developed for certain marine management scenarios.

\section{Contaminant Biodynamics for Fisheries Management}

As noted by Fowler et al. (2004), our understanding of the processes involved in the transfer of contaminants through coastal marine food chains can be greatly improved using nuclear techniques. Specifically, the ability to radioanalyze live organisms and the increased sensitivity of radiotracer detection allows for: (1) biological variation of individual organisms to be captured in experiments relative to conventional ecotoxicology studies not using radiotracers; (2) measuring contaminant biokinetics over the long term in a limited number of individuals; and (3) distinguishing dietary from aqueous sources of contaminants for marine that cannot be easily investigated using standard analytical techniques (Wang and Fisher, 1999). Furthermore, nuclear techniques allow experiments to be conducted using contaminant concentrations that are either well below or approximately close to those present in the natural waters. The uptake of contaminants by aquatic animals predominantly occurs via uptake of soluble elements through respiration (e.g., via gills) or, to a greater extent for most contaminants, uptake of solid-phase contaminants associated with diet via ingestion (Fowler and Fisher, 2005). Once internalized, it is important to understand how the organism processes the contaminant, either through detoxification/sequestration or release through excretory products back to the environment. If neither of these processes occur effectively, adverse effects/toxicity may ensue. Data on contaminant loss rates from an organism are a crucial part of biodynamic modeling (i.e., balance between uptake and loss), that can be quantified using radiotracers. Much of what is known about depuration rates has been evaluated through the use of radiotracers, but loss rates are usually assessed from individual whole animals rather than specific tissues or organs (with a few exceptions, including Cresswell et al., 2017a), so definitive predictions for loss rates for specific contaminants from different animals remain elusive. A more comprehensive assessment to explain loss rates of contaminants, using radiotracers, would enhance modeling efforts to describe the main uptake pathway of contaminants (e.g., Metian et al., 2016) or their transfer in aquatic food chains, and potentially improve predictions of contaminant concentrations in seafood.

In addition, assessment of depuration rates in commercially relevant seafood species could reduce the risk of consumer exposure to contamination by maintaining organisms a certain period of time in clean open-circuit water systems after the harvesting phase. Indeed, biokinetic parameters, such as biological half-life, inform the time needed to reduce the quantity of contaminant in seafood by half, compared to its initial levels.

\section{Effects of Abiotic and Biotic Factors on Metal Speciation and Bioavailability}

It has long been recognized that the chemical and physical speciation of metal contaminants can influence their bioavailability to aquatic organisms, including plants (e.g., phytoplankton) and animals. This has been extensively studied for metals dissolved in freshwater and seawater (Luoma and Rainbow, 2008; de Paiva Magalhães et al., 2015). However, quantification of the bioavailability of metal contaminants associated with sediments has remained a challenge, particularly in terms of the influence of metal speciation within sediments on bioavailability for benthic animals. While numerous studies have evaluated the bioaccumulation of metals from sediments (Luoma, 1989; Bryan and Langston, 1992; Wang et al., 1999), few have quantitatively assessed how metal speciation in sediments affects bioavailability to benthic fauna (Baumann and Fisher, 2011). Since redox conditions in sediments can change with eutrophication, particularly in coastal sediments, the speciation of metals, particularly those bound to iron and manganese oxides, may change seasonally, and hence affect their bioavailability for bottom-dwelling organisms.

The bioavailability of ${ }^{137} \mathrm{Cs}$ from contaminated sediments off Fukushima, Japan following the accident at the FukushimaDaiichi nuclear power plant, has resulted in higher levels of this contaminant in benthic fish than in pelagic fish in Japanese coastal waters (Buesseler et al., 2017; Wang et al., 2018). The 
speciation of sediment-bound Cs in those regions has not been fully explored, but evidence suggests that Cs can build up in benthic food chains through assimilation of Cs in depositfeeding worms that assimilate it from contaminated sediments and transfer it to fish or macroinvertebrates (Wang et al., 2016). In addition, physical factors have changed in the world's oceans (temperature, seawater $\mathrm{pH}$ ) and these may also affect the bioaccumulation of metals and radionuclides. The extent to which such physical factors may influence contaminant bioavailability remains to be determined. While it is difficult to replicate field conditions in controlled laboratory sorption experiments, radiotracers offer a rapid method for understanding the factors governing contaminant partitioning between the sediment, solution and suspended particulate phases that can aid in the interpretation of field data (Payne et al., 2004).

\section{Role of Microbes/Plankton in Contaminant Uptake}

The role of microbes in marine ecosystems and biogeochemical cycles are often assessed using radiotracers. The classic C14 assimilation method for measuring phytoplankton primary productivity (Nielsen, 1952) is commonly used in oceanography due to its sensitivity, allowing for high resolution measurements of relatively small volumes of seawater. Microbial biomass production is also similarly measured using compounds labeled with ${ }^{14} \mathrm{C}$ or ${ }^{3} \mathrm{H}$ that are incorporated into DNA or proteins, two biosynthesis pathways that scale with growth. The two most commonly used methods are thymidine and leucine incorporation (Fuhrman and Azam, 1980; Kirchman et al., 1985), which trace DNA and protein synthesis, respectively. Additional radiotracers, such as ${ }^{33} \mathrm{P}$ (Perry, 1976), ${ }^{35} \mathrm{~S}$ (Jørgensen and Fenchel, 1974), and ${ }^{55,}{ }^{59} \mathrm{Fe}$ (Hutchins et al., 1993) have been used to measure microbial uptake and turnover of macroand micro-nutrients, as well as alternative respiratory pathways like sulfate reduction in both seawater and marine sediments. In addition to rate measurements, the individual organisms involved in the uptake and cycling processes can be identified, visualized, and enumerated by combining autoradiography with fluorescent in situ hybridization (FISH) using targeted probes (Ouverney and Fuhrman, 1999).

In addition to assessing 'natural' microbial processes in the marine environment, the uptake of contaminants by microbes can also be explored using radiotracers (Fowler and Fisher, 2005). Due to their large surface area to volume ratios, phytoplankton efficiently accumulate metals and radionuclides in seawater through passive surface adsorption and absorption across cell membranes. Zooplankton similarly adsorb contaminants from seawater but can also accumulate them through ingestion of food. These micro-organisms then serve as vectors for the transfer of metals and radionuclides up into the marine food chain or deeper into the water column through particle transport. Laboratory experiments often label phyto- and zooplankton with radiotracers to serve as dietary vectors for contaminants of interest to higher order marine organisms (Willis and Sunda, 1984). In the field, size-fractionated measurements of contaminants on particulate matter via plankton nets and/or filtration can indicate the partitioning of these pollutants into the microbial component(s) of marine foodwebs and ecosystems (Buesseler et al., 2012). However, generally fewer radionuclide data exist for phytoplankton at the base of the food chain, compared to zooplankton and larger organisms.

\section{Specific Contaminants of Concern: $\mathrm{Hg} /$ Methyl-Hg, ${ }^{210}$ Po}

There are a number of contaminants that are capable of building up in marine food chains. This is particularly true for methylmercury ( $\mathrm{MeHg}$ ) which displays clear evidence of biomagnification (Morel et al., 1998; Reinfelder et al., 1998; Mathews and Fisher, 2008). Unlike inorganic $\mathrm{Hg}, \mathrm{MeHg}$ is highly assimilated by animals from their diet and is lost from animals at very low rates. Consequently, $\mathrm{MeHg}$ tends to increase significantly from one trophic level to another (i.e., biomagnification), and reaches very high concentrations in tissues of old, large, slow-growing predators (e.g., swordfish, tuna, sharks, whales). Given its toxic effects in seafood consumers (mostly neurological effects), there is considerable public health interest in following the bioaccumulation and trophic transfer of $\mathrm{MeHg}$ in aquatic food chains. Application of the beta/gammaemitting radioisotope ${ }^{203} \mathrm{Hg}$ (both inorganic and organic species) has been undertaken to study the biodynamics in marine food chains (Lee and Fisher, 2016, 2017) and may continue to elucidate how $\mathrm{MeHg}$ cycles in aquatic ecosystems.

Another important radionuclide that can accumulate in marine biota animals is the naturally occurring ${ }^{210} \mathrm{Po}$. This radionuclide is the last of the radioactive daughter products of ${ }^{238} \mathrm{U}$, which is ubiquitous in the world's oceans. ${ }^{210}$ Po is an alphaemitting radionuclide $(5.3 \mathrm{MeV})$ that primarily associates with proteins in animals (Heyraud and Cherry, 1979; Cherry and Heyraud, 1981, 1982). It is greatly enriched in phytoplankton at the base of marine food chains (Fisher et al., 1983; Stewart and Fisher, 2003) and can be efficiently transferred to zooplankton, and subsequently, larger animals along short food chains (Stewart et al., 2008). The resultant radiological dose to marine fish generally exceeds that of anthropogenic radionuclides (e.g., ${ }^{137} \mathrm{Cs}$ ) (Aarkrog et al., 1997), even in most fish exposed to ${ }^{137} \mathrm{Cs}$ in waters off Fukushima (Fisher et al., 2013). Given the potential importance of ${ }^{210} \mathrm{Po}$ dose to marine biota as a benchmark against which doses from anthropogenic radionuclides need to be assessed, it is important to better understand how ${ }^{210} \mathrm{Po}$ speciates in water and how it binds to specific proteins in marine organisms. While important inroads have been made through the pioneering work of Cherry and Heyraud (1981, 1982), clearly more research is warranted on the marine geochemical cycling and biochemistry of this radionuclide.

\section{U/Th Series Isotope Tracers to Examine the Marine Carbon Cycle}

${ }^{238} \mathrm{U}^{234} \mathrm{Th}$ and ${ }^{210} \mathrm{Po}-{ }^{210} \mathrm{~Pb}$ isotope pairs have been used extensively to estimate the seasonal to annual particulate organic carbon (POC) export and remineralization in the oceans. ${ }^{234} \mathrm{Th}$ $\left(t_{1 / 2}=24.1 \mathrm{~d}\right)$ is produced from the alpha decay of ${ }^{238} \mathrm{U}$ in the ocean. ${ }^{238} \mathrm{U}$ is a highly soluble and conservative element 
in seawater, whereas ${ }^{234} \mathrm{Th}$ is highly particle reactive. Similarly, ${ }^{210} \mathrm{Po}\left(t_{1 / 2}=138 \mathrm{~d}\right)$ is produced from the alpha decay of its grandparent ${ }^{210} \mathrm{~Pb}\left(t_{1 / 2}=22.3 \mathrm{y}\right)$ via ${ }^{210} \mathrm{Bi}\left(t_{1 / 2}=5.01\right.$ d). Both ${ }^{210} \mathrm{Po}-{ }^{210} \mathrm{~Pb}$ are variably particle reactive and ${ }^{210} \mathrm{Po}$ is highly reactive to biogenic particles (Stewart et al., 2008; Jones et al., 2015; Bam et al., 2020). The daughter and parent radioisotopes reach secular equilibrium (i.e., comparable activity concentrations; $\mathrm{Bq} / \mathrm{g}$ or $\mathrm{Bq} / \mathrm{mL}$ ) when parents are much longerlived relative to the daughter in a closed system and there have been multiple daughter half-lives experienced (BenitezNelson et al., 2018b). However, ${ }^{234}$ Th and ${ }^{210}$ Po are preferentially adsorbed onto sinking particles which 'disrupts' the parentdaughter secular equilibrium and can result in preferential isotopic ratios, which provides an estimate of the particle flux. Also, the scavenging of ${ }^{210} \mathrm{Po}^{210} \mathrm{~Pb}$ is driven by the difference in the affinities of the nuclides for active biological uptake versus passive adsorption (Nozaki et al., 1998). The flux of the radioisotope is calculated simply as follows:

$$
F=\lambda_{D} \int_{0}^{z}\left(A_{P}-A_{D}\right) d z
$$

where $F$ is the flux (dpm $\mathrm{m}^{-2} \mathrm{~d}^{-1}$ ) of daughter radioisotopes, $z$ is the depth of water column $(\mathrm{m}), \lambda_{\mathrm{D}}$ is decay constant of daughter $\left(\mathrm{d}^{-1}\right), A_{\mathrm{P}}$ and $A_{\mathrm{D}}$ are activities $\left(\mathrm{dpm} \mathrm{L} \mathrm{L}^{-1}\right)$ of parent and daughter radioisotopes in the water column respectively. ${ }^{234} \mathrm{Th}$ provides a flux rate integrated over a few weeks (Buesseler et al., 1998, 2001), which coincides with the residence time of biological particles in the upper ocean. Thus, ${ }^{234} \mathrm{Th}$ based flux is useful to estimate and/or rule out POC-flux due to short-term local blooms, upwelling or temporary disruption. ${ }^{210}$ Po provides a flux rate integrated over several months. The export fluxes of these daughter radionuclides can be converted to the POC export flux as follows:

$$
F_{P O C}=F_{R}\left[\frac{P O C}{R}\right]_{\text {sinking particles }}
$$

where $F_{\text {POC }}$ is flux of POC (mg C m $\left.{ }^{-2} \mathrm{~d}^{-1}\right), F_{\mathrm{R}}$ is flux of radioisotope $\left({ }^{234} \mathrm{Th}\right.$ or ${ }^{210} \mathrm{Po}$; $\left.\mathrm{dpm} \mathrm{m}^{-2} \mathrm{~d}^{-1}\right)$, POC is particulate organic carbon concentration $\left(\mathrm{mg} \mathrm{C} \mathrm{L}^{-1}\right)$ and $R$ is the activity $\left(\mathrm{dpm} \mathrm{L} \mathrm{L}^{-1}\right)$ of radioisotope $\left({ }^{234} \mathrm{Th}\right.$ or ${ }^{210} \mathrm{Po}$; dpm $\left.\mathrm{L}^{-1}\right)$. For example, Maiti et al. (2016) has estimated the carbon flux using both ${ }^{210} \mathrm{Po}$ and ${ }^{234} \mathrm{Th}$. Here, we present the profiles of ${ }^{234} \mathrm{Th}:{ }^{238} \mathrm{U}$ and ${ }^{210} \mathrm{Po}:{ }^{210} \mathrm{~Pb}$ (Figures 1A,B) adapted from Maiti et al. (2016). Net disequilibria of ${ }^{234} \mathrm{Th}:{ }^{238} \mathrm{U}$ and ${ }^{210} \mathrm{Po}:{ }^{210} \mathrm{~Pb}$ integrated relative to depth can be used to estimate the flux of ${ }^{234} \mathrm{Th}$ and ${ }^{210} \mathrm{Po}$, which is then used to calculate the carbon flux, as shown in Figure 1C.

Multiple studies have shown that the ${ }^{234}$ Th-based POC fluxes are similar to ${ }^{210} \mathrm{Po}$-based fluxes, falling within a factor of 0.8 to 1.8 (Gulf of Mexico; Figure 1C; Maiti et al., 2016), 0.5 (Equatorial Pacific; Murray et al., 2005), 0.9 to 3.4 (Mediterranean Sea; Stewart et al., 2007), 0.74 to 2.3 (South China Sea; Wei et al., 2011). These differences in the ${ }^{234} \mathrm{Th}$ and ${ }^{210}$ Po based fluxes might due the fact that one must assume: (1) steady state conditions and minimal physical processes; (2) negligible advective and diffusive fluxes; and (3) most importantly, daughter radionuclide deficit is caused due to the preferential scavenging of daughter radionuclide relative to parent radionuclide (Maiti et al., 2016; Tang and Stewart, 2019). The adsorption and scavenging of radionuclides are influenced by the concentration and composition of the particles (Roberts et al., 2009; Tang et al., 2017).

The concentration and composition of the particles in the ocean is changing due to higher sediment input from the coastal erosion, high riverine input, changes in terrestrial organic matter input and exponentially increasing amounts of micro- and nanoplastic particles (Rachold et al., 2004; Chen et al., 2012; Jambeck et al., 2015; Basu and Mackey, 2018; Zheng et al., 2018). Further, the ocean chemistry is rapidly changing due to climate change, expansion of oxygen minimum zones and high sediment loads in estuarine and coastal areas. It is estimated that 4-12 million tons of plastic was transferred to the ocean annually in 2010 and it is expected to increase by an order of magnitude by 2025 at the current rate (Jambeck et al., 2015). These changes in particle type, origin, shape and size might influence the way radioisotopes can be used to study the particle fluxes, as the affinity of adsorption and sorption of these radionuclides is different for different particle types and sizes.

Atmospheric $\mathrm{CO}_{2}$ is converted into POC by phytoplankton in the ocean (Figure 2). A portion of the POC can be exported to the deeper ocean by sinking particles, while some amount of POC can also be converted to dissolved organic carbon (DOC). Transparent exopolymer particles (TEP) are carbon-rich, extracellular particles formed by the accumulation of DOC and can aggregate and sink along with POC (Arrigo, 2007). Increased $\mathrm{CO}_{2}$ in the atmosphere can increase the POC in the surface water and impact ocean acidification. Ocean acidification could lead to increase in the abundance of TEP (Arrigo, 2007; Louis et al., 2017). TEP enhances the particle aggregation and sinking of aggregated particles influenced by the POC export (Mari et al., 2012; Louis et al., 2017). The change in primary productivity, and consequently increases in phytoplankton and algal blooms events, are becoming more frequent in global oceans (Hallegraeff, 2010; Wells et al., 2015; Schulz et al., 2017). The increased sinking of phytoplankton after the bloom events cause high POC export (Kessouri et al., 2017; Roca-Martí et al., 2017).

It is important to understand how plastic gyres, plastics leaching DOC, and biofilms using plastics as substrates will impact the particle dynamics, phytoplankton and zooplankton communities and carbon export in the global ocean. Plastic pellets act as a transport medium for different chemicals and trace metals, such as zinc, copper, cadmium, and lead, via sorption and desorption processes (Mato et al., 2001; Munier and Bendell, 2018), and for the radionuclides, ${ }^{137} \mathrm{Cs}$ and ${ }^{90} \mathrm{Sr}$ (Johansen et al., 2019b). In future, studies should focus on the kinetics of sorption and desorption of organic matter and radionuclides to plastics to better quantify the carbon export. Further, Romera-Castillo et al. (2018) have suggested that DOC leaching from plastics in the oceans may have unaccounted effects to the marine organic carbon cycle.

Future studies should focus on the how the changing physical, chemical, and biological conditions in the ocean environment change the aggregation, sinking, and export rates of the POC, as well as other sinking particles. The coupled use of radioisotope 


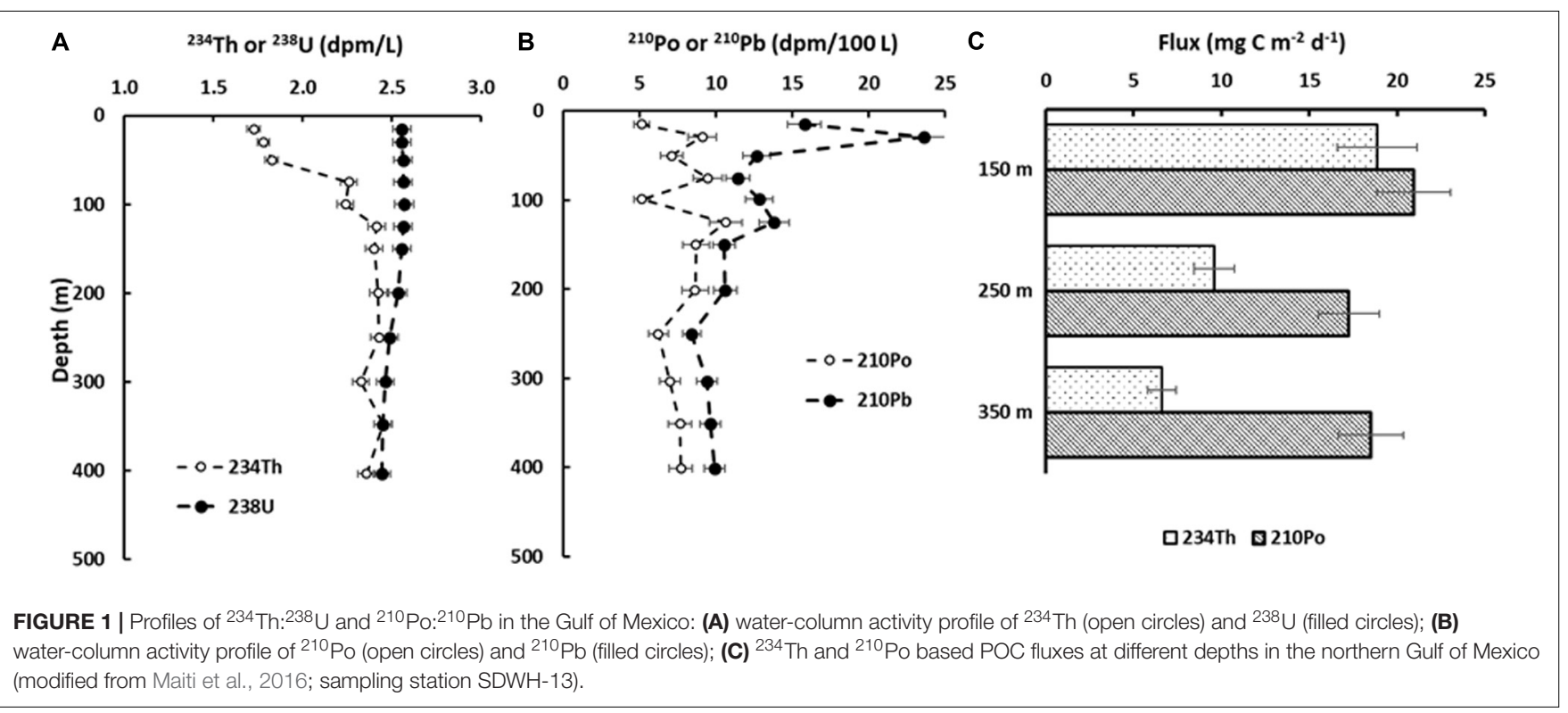

tracers and stable isotopes of carbon and nitrogen could be beneficial to better estimate POC export, differentiate the source of POC and DOC (plastic-derived, terrestrial and marine) and understand the remineralization of organic carbon in the ocean.

\section{Role of Metals in HABs Biotoxin Production}

The initiation of harmful algal blooms (HABs) and their production of biotoxins remains an open question, although such blooms almost certainly require specific environmental

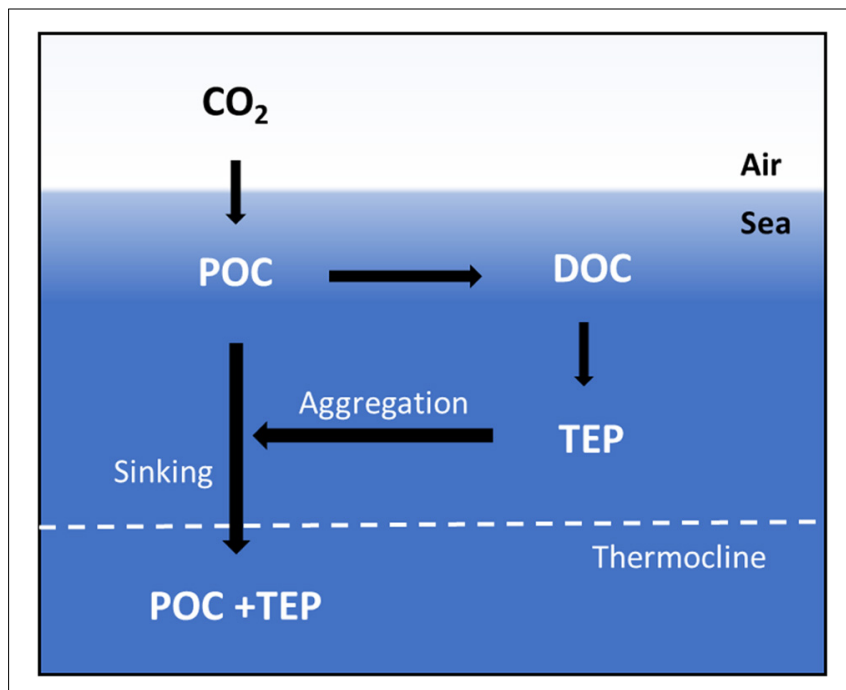

FIGURE 2 | Idealized schematic of the marine carbon cycle, as adapted from Arrigo (2007). $\mathrm{CO}_{2}$ is converted into particulate organic carbon (POC) by phytoplankton. A component of the POC is exported to the deeper ocean by sinking particles, while some amount of POC is converted to dissolved organic carbon (DOC). Transparent exopolymer particles (TEP) aggregate and sink with POC. conditions (i.e., temperature, light, nutrients). In addition to the influence of trace metals on phytoplankton through nutrient limitation, as well as toxicity, their bioavailability may also be implicated in stimulating toxin-producing HABs (Sunda, 2006). Most well-studied may be the occurrence of Pseudonitzschia and the neurotoxin, domoic acid, following iron fertilization experiments or with the addition of copper (Maldonado et al., 2002; Wells et al., 2005; Silver et al., 2010; Trick et al., 2010). Other studies have linked trace elements, such as $\mathrm{Li}$, $\mathrm{Se}$, and $\mathrm{Ni}$, to $\mathrm{HAB}$ species (Kudela et al., 2010). Algalbacterial interactions may also be involved in bloom dynamics, with siderophore-producing bacteria potentially supplying iron to HAB species (Yarimizu et al., 2018). Given the potential links between various trace metals and HAB toxin production, the use of sensitive radiotracers, such as ${ }^{59} \mathrm{Fe}$, would enable experiments with environmentally relevant concentrations of elements potentially implicated in $\mathrm{HAB}$ initiation, biotoxin production, and physiology. Radiotracer techniques would allow for precise detection of trace elements and potentially identify their location within cells or in the surrounding phycosphere.

\section{EXISTING AND EMERGING ISSUES THAT WILL BENEFIT FROM CURRENT AND NEW RADIOTRACER TECHNIQUES}

\section{Development of New Applications of Existing Radiotracers to Address Marine Processes}

In light of these many and varied applications of radiotracers toward understanding marine ecosystem processes, there are additional areas where existing techniques could be further developed to address under-explored outstanding research questions. Ongoing development in the use of natural abundance radiocarbon $\left({ }^{14} \mathrm{C}\right)$ distributions throughout the 
marine environment (both inorganic and organic in seawater, sediments, and biota) continues to enhance our understanding of critical aspects of the marine carbon cycle and ocean circulation and ventilation as a whole (Broecker and Peng, 1982; Matsumoto, 2007; McNichol and Aluwihare, 2007). For example, ${ }^{14} \mathrm{C}$ measurements on DOC fractions and even specific compounds and biomarkers (Close, 2019), are increasingly possible due to analytical innovations leading to decreased sample size requirements. Furthermore, these measurements can be used to probe both age and lability of various components of the DOC pool. Although the systematic increased resolution of dissolved inorganic carbon ${ }^{14} \mathrm{C}$ measurements, initiated as part of the World Ocean Circulation Experiment (WOCE), has led to unprecedented insight into the carbon reservoir of the interior ocean and its role in regulating climate ( $\mathrm{McNichol}$ et al., 2000), increased demand for other types of ${ }^{14} \mathrm{C}$ measurements can drive technical method innovation, resulting in lower costs, smaller required sample sizes, and reduced analysis time. As ocean conditions are changing along with changes in the global climate, existing radiotracers can be applied to new systems within marine environments. For example, radiotracers commonly used to track processes in anoxic sediments can be adapted for use in water column oxygen minimum zones and expanding low oxygen regions of the global ocean. Furthermore, combining radiotracers with other analytical techniques, such as liquid chromatography-mass spectrometry (LC-MS), can link biomarker identification to specific metabolic processes that have biogeochemical implications in marine systems, such as the assimilation of carbon or lipid biosynthesis in marine organisms (Evans et al., 2018, 2019).

\section{Multiple Stressors; Multiple Contaminants, and Environmental Stressors}

Marine organisms and ecosystems are exposed to a wide range of environmental changes due to human activities. Some of the changes are global, whereas others are regional or local. These wide-ranging changes are often referred to as drivers or stressors (Boyd et al., 2018). The multiple drivers framework represents a complex matrix of changing ocean properties that will vary from locale to locale, and may also change with season. A wide range of perturbation experiments can be used to better understand how multiple drivers influence marine life (Boyd et al., 2018). Radiotracers could be used to assess the effect of environmental stressors on the bioaccumulation of an element, including bioconcentration or trophic transfer. In recent years, focus was placed to understand the effect of ocean acidification on metal bioaccumulation in marine organisms such as cadmium (Cao et al., 2018). These studies highlight the main advantage of using gamma-emitter radiotracers including: (1) the ability to radioanalyze the same individual live organisms over time, thereby reducing biological variability between samples; and (2) the possibility to conduct experiments at contaminant concentrations that are below or comparable to those present in the environment. Working with stable metals, analytical protocols commonly require higher, more environmentally unrealistic experimental concentrations of metals and also require more time for conducting analyses.

Nuclear techniques can also highlight some physiological responses and be considered as "proxies" for physiological change in aquatic species. Radiotracers, such as ${ }^{65} \mathrm{Zn}$, have been used in the past, but nuclear techniques, such as nuclear magnetic resonance spectroscopy (NMR), allow the determination of metabolic profiles of tissues, organs or individuals (Viant et al., 2003) under multiple sets of conditions (such as ocean warming, acidification and hypoxia, e.g., Schmidt et al., 2017; TrippValdez et al., 2017; Götze et al., 2020) and with different environmental stressors (e.g., heavy metals, Lannig et al., 2010; Cappello et al., 2016).

\section{Impact of Physiological Processes on Contaminant Uptake and Loss}

It has been well documented that physiological process can impact contaminant bioaccumulation processes (Luoma and Rainbow, 2008) and the use of radiotracers can greatly enhance the understanding of such processes. It has been well documented that molting (shedding of exoskeleton) in decapod crustaceans can affect the accumulation kinetics of metals using radiotracer. For example, Cresswell et al. (2015) found that cadmium and zinc uptake in freshwater decapods (Macrobrachium australiense) returned to an intermolt rate of uptake 2-3 days post-molt, which may be due to the exoskeleton no longer being as permeable by that stage, or due to a decrease in calcium pump rates as the exoskeleton hardens. However, White and Rainbow $(1984,1986)$ observed that the rate of cadmium and zinc uptake in post-molt marine decapods (Palaemon elegans) continued to be enhanced and had not returned to pre-molt rates by the time each study ended, with the time from molt to the end of the studies occurring between $36 \mathrm{~h}$ and 8 days. O'Mara et al. (2019) detected an increase in the uptake of manganese and zinc in marine school prawns (Metapenaeus macleayi) that had molted, compared to those that did not molt during aqueous exposure.

Radiotracers have also been used to study how significant physiological changes, such as metamorphosis in amphibians, can affect contaminant bioaccumulation. Lanctôt et al. (2017) used radiotracers of selenium $\left({ }^{75} \mathrm{Se}\right)$ to study the role of tissue degeneration and remodeling during anuran metamorphosis as a mechanism for examining tissue-specific contaminant burdens. The study with the Australian striped marsh frog, Limnodynastes peronii, demonstrated that selenium biodistribution (i.e., organ distribution) varies significantly throughout metamorphosis (Figure 3).

\section{Integration of Stress/Energy Biomarkers With Radiotracer Contaminant Studies}

As mentioned before, an assessment of the effect of environmental stressors on organisms can be conducted by testing their responses using nuclear techniques. For example, in metabolomics (the scientific study of chemical processes involving metabolites), NMR provides a useful technique for profiling metabolites and has been used for assessing the impact of environment stressors on marine organism over almost 


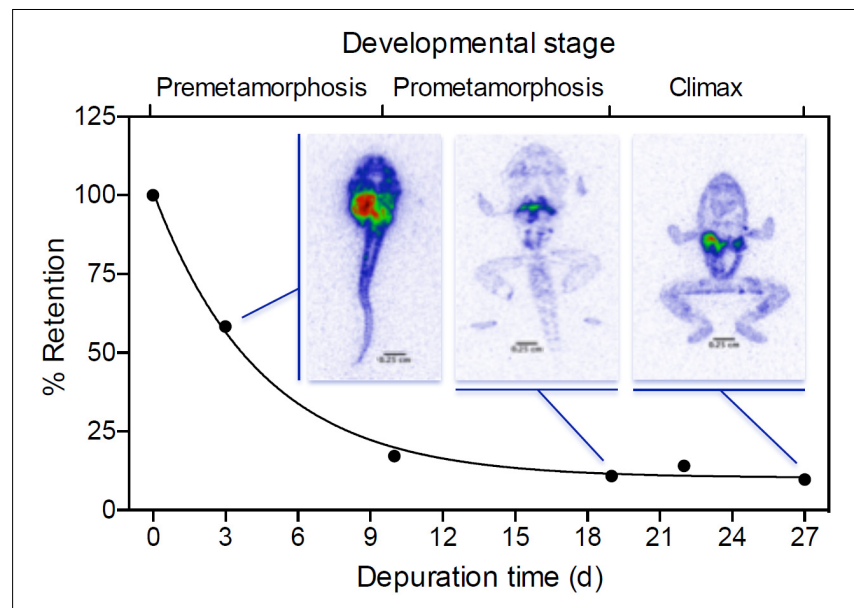

FIGURE 3 | Retention (\%) of selenium (Se) in whole tadpoles (following exposure for 7 days) sampled at different developmental stages throughout 27 days of depuration in clean water. Line shows the best-fit one-phase exponential decay $\left(R^{2}=0.83\right)$. Digital autoradiographic false color phosphor images show Se distribution in ventral sections of tadpoles at developmenta stage 33, 42, and 46 (Gosner, 1960), sampled after 3, 19, and 27 of depuration in clean water, respectively. Reprinted (adapted) with permission from Lanctôt et al. (2017). Copyright (2017) American Chemical Society.

20 years (Viant et al., 2003; Lannig et al., 2010; Lankadurai et al., 2013; Tikunov et al., 2014; Cappello et al., 2016). Metabolomics consists of a large-scale study of small molecules, commonly known as metabolites, within cells, biofluids, tissues and/or organisms. Untargeted metabolic profiling, based on NMR spectroscopy, is a powerful approach because of its holistic nature and because metabolites and their concentrations directly reflect the underlying biochemical activity and state of cells and tissues.

Another type of magnetic resonance spectroscopy has been also used toward this aim. In vivo magnetic resonance spectroscopy (MRS) is a specialized non-destructive technique associated with magnetic resonance imaging (MRI). This technique is a non-invasive, ionizing-radiation-free analytical technique that has been used to study metabolic changes in human patients in the last century (Lauterbur et al., 1980; Bell and Bhakoo, 1998). However, developments have been made in marine ecology and comparative physiology, more particularly, in the assessment of physiological (energetic) status of marine organisms, such as mollusks or fish, under changing environmental conditions (Bock et al., 2002, 2019). Mainly, two in vivo techniques have been used: proton magnetic resonance spectroscopy $\left({ }^{1} \mathrm{H}-\mathrm{MRS}\right)$ and ${ }^{31} \mathrm{P}$ magnetic Resonance Spectroscopy ( $\left.{ }^{31} \mathrm{P}-\mathrm{MRS}\right) .{ }^{1} \mathrm{H}-\mathrm{MRS}$ is able to quantify the abundance of neurochemicals, such as neurotransmitters and metabolites like amino acids, but also anaerobic end products, such as lactate, and is also used for fat and lipid analysis (Bock et al., 2017; Wermter et al., 2018). ${ }^{31}$ P-MRS measures phosphorus-containing metabolites that play an essential role in physiology. The most important are the high-energy phosphates, ATP and phosphagen (creatine phosphate or phospho-l-arginine) and their end product, inorganic phosphate, to address the energy status. Furthermore, the ${ }^{31} \mathrm{P}-\mathrm{NMR}$ signal of inorganic phosphate can be used to follow acid-base regulation of cells and tissues in the same spectrum (Bock et al., 2019). Recently, in vivo ${ }^{13} \mathrm{C}-\mathrm{NMR}$ spectroscopy was introduced to study metabolic pathways in marine organisms under environmental stress (Tikunov et al., 2014).

NMR has also had substantial utility in phosphorous speciation studies, and has resulted in increased understanding of the modern phosphorous cycle in both terrestrial soils and aquatic sediment. For example, ${ }^{31} \mathrm{P}-\mathrm{NMR}$ has been used successfully in studying the speciation of phosphorous in Chesapeake Bay to better understand nutrient contamination and dynamics (Li et al., 2015) and ${ }^{1} \mathrm{H}_{-}{ }^{31} \mathrm{P}$ NMR correlation spectroscopy has been used to characterize the organic phosphorous fractions in soil which has resulted in an increased understanding of phosphorous biogeochemistry (Vestergren et al., 2012). All of these NMR spectroscopy techniques are quite unique and could be used for the future development of nuclear techniques toward the assessment of the physiological impacts of environment stressors.

Other nuclear-derived techniques, such as the polymerase chain reaction (PCR), reverse transcription PCR and enzymelinked immunosorbent assay, are important tools to rapidly and efficiently identify and characterize environmental stress caused to marine organisms (Boutet et al., 2002; Peck et al., 2011; Huo et al., 2018).

\section{Development of Radio-Assays for HAB Biotoxin Detection; Adapting Nuclear Receptor Binding Techniques for a Range of Marine Biotoxins}

The frequency and scales of today's HAB constitute a growing worldwide problem, negatively affecting aquatic ecosystems, public health and local economies. HAB events have been shown to cause oxygen depletion, phycotoxin production, mucilage, reactive oxygen species, and polyunsaturated fatty acids. HAB can also trigger systematic damage to tissue and cells of marine organisms and can even cause catastrophic mortalities in commercially important fish species, as well as marine mammals and sea turtles (Anderson, 2017). Worldwide, the occurrence of $\mathrm{HAB}$ appears to have increased in frequency, geographic extent and intensity, which may be due to heightened nutrient discharges, but also climate change impacts, such as warming and water column stratification (Heisler et al., 2008), as well as the introduction of exotic species (van den Bergh et al., 2002). Most of the HAB species are dinoflagellates, accounting for as much as 100 taxa in the marine environment (Mouestrup et al., 2009).

Paralytic shellfish toxins (PSTs) and ciguatoxins can be effectively and quickly analyzed in marine biota using the receptor binding assay (RBA) technique (IAEA, 2013). Briefly, the RBA method quantifies the toxin potency by determining, through a scintillation counter, the concentration of tritiated toxin standards, which compete with the toxin from sample extracts for binding to voltage-gated sodium channels in a rat brain membrane preparation (Van Dolah et al., 2012). 
The establishment of effective HAB early warning systems, the adoption of robust molecular techniques to improve rapid identification methods of HAB-forming species, and necessary expansion into freshwater ecosystems should all be developed and strengthened to ameliorate potential deleterious impacts of new HAB events (Cuellar-Martinez et al., 2018).

\section{Maternal Transfer of Contaminants, Including Intergenerational Transfer}

Among the different exposure pathways studied separately in the past using radiotracers, there was water, food, and sediment (Casado-Martinez et al., 2009; Metian et al., 2010; Wang, 2011; Cresswell et al., 2014), but episodically, a fourth pathway has been investigated: the maternal transfer of contamination (viz. transfer of contaminants from the mother to the eggs or the juveniles; e.g., Lacoue-Labarthe et al., 2008; Jeffree et al., 2015). It has been shown that in some marine organisms, maternal transfer is metal-dependent and while eggs can concentrate some elements, juveniles might be safe due to protective mechanisms (Lacoue-Labarthe et al., 2008). Gamma-emitting radiotracers are the ideal tools to assess such transfer. In the same vein, it is also possible to look at more than one generation transfer (i.e., transgenerational), but this requires some specific species with a short life-cycle (such as Daphnia spp.; see Lam and Wang, 2006).

Radiolabeled organic compounds are also part of the radiotracer toolkits to examine the bioaccumulation of organic compounds in aquatic organisms. Although they are mainly labeled with ${ }^{14} \mathrm{C}$, some tritium-labeled compounds are also used. A large range of compounds exist, from polychlorinated biphenyls (PCBs) to benzo(a)pyrene (BaP) and include surfactants (e.g., linear alkylbenzene sulfonates; Metian et al., 2019b), pesticides and polycyclic aromatic hydrocarbons (PAHs) (Danis et al., 2005; Wang and Wang, 2006; Berrojalbiz et al., 2009; Renaud et al., 2014). Radiolabeled organic contaminants are usually beta-emitters, and unlike gamma-emitters, radiocounting individuals over time is impossible due to the analytical methods usually used to detect organic radiotracers (scintillation counting). This means that the description of kinetics requires destruction of the samples and a higher number of organisms. Nevertheless, the main advantage is the high degree of sensitivity of radio-detection methods compared to standard analytical techniques (Fowler et al., 2004), which allow investigating the bioaccumulation of organic contaminants which occur at very low environmental concentrations, such as individual $\mathrm{PCB}$ congeners or organic metabolites.

\section{Instrument Improvements for the Analysis of Environmental Samples}

The general low level of radionuclides in environmental samples and/or the small sample sizes available have required the use of efficient techniques. As outlined by Povinec (2017), the transition from counting of radioactive decays to counting atoms using mass spectrometry methods (Accelerator Mass SpectrometryAMS, Inductively Coupled Plasma-Mass Spectrometry-ICP-MS, Resonance Ionization Mass Spectrometry-RIMS, Secondary Ion Mass Spectrometry-SIMS, Thermal Ionization Mass
Spectrometry-TIMS) is a major paradigm shift in radioanalytical technology. Several of these latter methods have been adapted over the last decades to cover a wide span of environmental samples and radionuclides. Such analyses include: the quantification of key radionuclides, such as ${ }^{129} \mathrm{I}$ at very low levels at the Savannah River site in the United States, where speciation studies of iodine were conducted using AMS (Garcia-Leon, 2018); the analysis of ${ }^{240} \mathrm{Pu} /{ }^{239} \mathrm{Pu} /{ }^{241} \mathrm{Pu}$ isotope ratios in waters, sediments, terrestrial soils and marine and terrestrial biota using AMS to understand the fate of $\mathrm{Pu}$ and other radionuclides from former nuclear weapons testing in the Montebello Islands, Australia (Johansen et al., 2019a); the development of ICP-MS and coupling with linear quadrupole, time of flight (TOF), and Fourier transform ion cyclotron resonance (FTICR) to analyze environmental samples for radionuclides in a relatively cost-effective way (Roos, 2008), especially for ${ }^{135} \mathrm{Cs} /{ }^{137} \mathrm{Cs}$ ratios via ICP-MS with the development of interference separation methods (Russell et al., 2015); and the determination of ${ }^{99} \mathrm{Tc}$ in environmental samples through the development of chemical separation, combined with traditional radioanalytical techniques and mass spectrometric measurement techniques, to undertake safety assessments and decommissioning of nuclear facilities, as well to study water mass movement, exchange and circulation in oceanography (Shi et al., 2012).

These advances in analytical instrumentation to detect ultra-trace concentrations of radionuclides, down to $0.1 \mathrm{fg}$ levels (López-Lora and Chamizo, 2019), is providing a deeper understanding of the fate of contaminants and water mass movement in marine systems.

\section{CHALLENGES AND OPPORTUNITIES}

While the use of radioecological tracers has been practiced for nearly 60 years, today there is a real risk that these techniques will be lost, as fewer and fewer scientists are active in this field. This is partly due to the high regulatory and safety requirements for the shipment, storage, use (including personnel training) and disposal of radioactive materials, and partly to the lack of training in radiochemical and radiobiological methods in recent decades. A new generation of scientists with radioecological skills is needed to evaluate nuclear accidents (such as at Fukushima), advise on siting and potential impacts of new nuclear installations, and advise on decommissioning of aging nuclear power plants (Fisher et al., 2015). Further, it is important for the environmental science community to continue to support and train new scientists in the field of radioecological tracers to develop new techniques to apply to emerging coastal and marine ecosystem issues. By combining conventional environmental biological and chemical techniques with radioecological tracing techniques, a greater understanding of the coastal and marine ecosystem condition can be achieved. The development of radioecological tracer techniques should focus on addressing specific environmental issues, such as changes in animal physiology in response to changing climatic conditions and anthropogenic stressors, especially in combination with emerging 'omic' techniques (e.g., to detect genes, mRNA, proteins and 
metabolites in biological samples). This will greatly increase the ability of environmental managers to conduct evidence-based management of coastal and marine ecosystems.

One problem in working with radioisotopes is the difficulty in obtaining permits to conduct experiments in field situations. While some studies have taken advantage of using radioisotopes to explore how metals behave in natural settings (Dahlgaard, 1986; Fisher et al., 1996), increasingly, such studies have become difficult due to legal and administrative constraints. The few experiments that have compared lab and field behaviors of radionuclide processing by marine biota have indicated small differences, so laboratory simulations may be generally applicable to field situations. Moreover, modeling of metal bioaccumulation in aquatic animals that use key laboratory-generated criteria (uptake rate constants, assimilation efficiencies, efflux rate constants) has consistently shown that predictions closely match independent field measurements of metal bioaccumulation in diverse invertebrates and fish (Fisher et al., 1996, 2000; Wang et al., 1996; Roditi et al., 2000; Baines et al., 2002; Luoma and Rainbow, 2008; Mathews and Fisher, 2009; Baumann and Fisher, 2011; Dutton and Fisher, 2014). Thus, it appears that laboratory generated data can be applicable to real-world situations for many metals and metalloids. However, experimental work with large animals typically preclude laboratory experimentation and it is therefore often difficult to make comparisons between modeled tissue concentrations for these animals based on lab measurements and field measurements.

The use of radioecological tracers can increase the complexity of the experimental design (i.e., study contaminant mixtures during multiple environmental stressors such as $\mathrm{pH}$ and

\section{REFERENCES}

Aarkrog, A., Baxter, M. S., Bettencourt, A. O., Bojanowski, R., Bologa, A., Charmasson, S., et al. (1997). A comparison of doses from ${ }^{137} \mathrm{Cs}$ and ${ }^{210} \mathrm{Po}$ in marine food: a major international study. J. Environ. Radioact. 34, 69-90. doi: 10.1016/0265-931x(96)00005-7

Anderson, D. M. (2017). "Harmful algal blooms," in Harmful Algal Blooms (HABs) and Desalination: A Guide to Impacts, Monitoring and Management, eds D. M. Anderson, S. F. E. Boerlage, and M. B. Dixon (Paris: Intergovernmental Oceanographic Commission of UNESCO), 17-52.

Appleby, P. G. (2008). Three decades of dating recent sediments by fallout radionuclides: a review. Holocene 18, 83-93. doi: 10.1177/0959683607085598

Arrigo, K. R. (2007). Marine manipulations. Nature 450, 491-492. doi: 10.1038/ 450491a

Baines, S. B., Fisher, N. S., and Stewart, R. (2002). Assimilation and retention of selenium and other trace elements from crustacean food by juvenile striped bass (Morone saxatilis). Limnol. Oceanogr. 47, 646-655. doi: 10.4319/lo.2002. 47.3.0646

Bam, W., Maiti, K., Baskaran, M., Krupp, K., Lam, P. J., and Xiang, Y. (2020). Variability in ${ }^{210} \mathrm{~Pb}$ and ${ }^{210} \mathrm{Po}$ partition coefficients (Kd) along the US GEOTRACES Arctic transect. Mar. Chem. 219:103749. doi: 10.1016/j.marchem. 2020.103749

Baskaran, M. (ed.) (2011). Handbook of Environmental Isotope Geochemistry. Berlin: Springer-Verlag.

Basu, S., and Mackey, K. R. M. (2018). Phytoplankton as key mediators of the biological carbon pump: their responses to a changing climate. Sustainability 10:869. doi: 10.3390/su10030869

Baumann, Z., and Fisher, N. S. (2011). Modeling metal bioaccumulation in a deposit-feeding polychaete from labile sediment fractions and from pore temperature), increase data representativeness and quality through studying the fate of contaminants in individual organisms rather than pooled organisms, reduce the number of organisms required in experimental assays (Cresswell et al., 2017b), and reduce the requirement for destructive use of animals to align with initiatives, such as the National Centre for Replacement, Refinement and Reduction of Animals in Research $\left(\mathrm{NC} 3 \mathrm{Rs}^{2}\right)$; and allow for more rapid and more accurate detection of experimental analytes. This is especially the case where such analytes exist in high background concentrations, such as zinc.

\section{AUTHOR CONTRIBUTIONS}

All authors participated in a planning meeting for an IAEA Cooperative Research Project, held in Monaco in December 2018. All authors prepared content for their associated sections. TC compiled content from all authors and prepared the final version. All authors have reviewed and agreed to the submission of the final version.

\section{ACKNOWLEDGMENTS}

The IAEA is grateful for the support provided to its Environment Laboratories by the Government of the Principality of Monaco. This contribution was made within the framework of the IAEA CRP on "Applied radioecological tracers to assess coastal and marine ecosystem health" (K41019).

\footnotetext{
${ }^{2}$ www.nc3rs.org.uk
}

water. Sci. Total Environ. 409, 2607-2615. doi: 10.1016/j.scitotenv.2011. 03.009

Beaumont, N. J., Aanesen, M., Austen, M. C., Börger, T., Clark, J. R., Cole, M., et al. (2019). Global ecological, social and economic impacts of marine plastic. Mar. Pollut. Bull. 142, 189-195. doi: 10.1016/j.marpolbul.2019.03.022

Bell, J. D., and Bhakoo, K. K. (1998). Metabolic changes underlying 31P MR spectral alterations in human hepatic tumours. NMR Biomed. 11, 354-359. doi: 10.1002/(sici)1099-1492(1998110)11:7<354::aid-nbm515>3.0.co;2-n

Benitez-Nelson, C. R., Buesseler, K., Dai, M., Aoyama, M., Casacuberta, N., Charmasson, S., et al. (2018a). Radioactivity in the marine environment: cosmogenic and anthropogenic radionuclides. Limnol. Oceanogr. ELect. 8, 114-169. doi: 10.1002/loe2.10008

Benitez-Nelson, C. R., Buesseler, K., Dai, M., Aoyama, M., Casacuberta, N., Charmasson, S., et al. (2018b). Radioactivity in the marine environment: understanding the basics of radioactivity. Limnol. Oceanogr. ELect. 8, 1-58. doi: 10.1002/loe2.10010

Berrojalbiz, N., Lacorte, S., Calbet, A., Saiz, E., Barata, C., and Dachs, J. (2009). Accumulation and cycling of polycyclic aromatic hydrocarbons in zooplankton. Environ. Sci. Technol. 43, 2295-2301. doi: 10.1021/es8018226

Bock, C., Sartoris, F.-J., and Pörtner, H.-O. (2002). In vivo MR spectroscopy and MR imaging on non-anaesthetized marine fish: techniques and first results. Magn. Reson. Imaging 20, 165-172. doi: 10.1016/S0730-725X(02)00482-4

Bock, C., Wermter, F., Schalkhausser, B., Blicher, M. E., Pörtner, H. O., Lanning, G., et al. (2019). In vivo ${ }^{31} \mathrm{P}-\mathrm{MRS}$ of muscle bioenergetics in marine invertebrates: future ocean limits scallops' performance. Magn. Reson. Imaging 61, 239-246. doi: 10.1016/j.mri.2019.06.003

Bock, C., Wermter, F. C., and Mintenbeck, K. (2017). MRI and MRS on preserved samples as a tool in fish ecology. Magn. Reson. Imaging 38, 39-46. doi: 10.1016/ j.mri.2016.12.017 
Boutet, I., Tanguy, A., Auffret, M., Riso, R., and Moraga, D. (2002). Immunochemical quantification of metallothioneins in marine mollusks: characterization of a metal exposure bioindicator. Environ. Toxicol. Chem. 21, 1009-1014. doi: 10.1002/etc.5620210517

Bowles, M. C., and Livingston, H. D. (1997). U.S. Joint Global Ocean Flux Study (JGOFS). Available online at: http://usjgofs.whoi.edu/overview.html (accessed October 23, 2019).

Boyd, P. W., Collins, S., Dupont, S., Fabricius, K., Gattuso, J.-P., Havenhand, J., et al. (2018). Experimental strategies to assess the biological ramifications of multiple drivers of global ocean change-A review. Glob. Change Biol. 24, 2239-2261. doi: $10.1111 / \mathrm{gcb} .14102$

Broecker, W. S., and Peng, T.-H. (1982). Tracers in the Sea. Palisades, N.Y: Eldigio Press.

Bryan, G. W., and Langston, W. J. (1992). Bioavailability, accumulation and effects of heavy metals in sediments with special reference to United Kingdom estuaries: a review. Environ. Pollut. 76, 89-131. doi: 10.1016/0269-7491(92) 90099-V

Buesseler, K., Dai, M., Aoyama, M., Benitez-Nelson, C., Charmasson, S., Higley, K., et al. (2017). Fukushima Daiichi-derived radionuclides in the ocean: transport, fate, and impacts. Annu. Rev. Mar. Sci. 9, 173-203. doi: 10.1146/annurevmarine-010816-060733

Buesseler, K. O., Ball, L., Andrews, J., Benitez-Nelson, C., Belastock, R., Chai, F., et al. (1998). Upper ocean export of particulate organic carbon in the Arabian Sea derived from thorium-234. Deep Sea Res. Part II Top. Stud. Oceanogr. 45, 2461-2487. doi: 10.1016/s0967-0645(98)80022-2

Buesseler, K. O., Ball, L., Andrews, J., Cochran, J. K., Hirschberg, D. J., Bacon, M. P., et al. (2001). Upper ocean export of particulate organic carbon and biogenic silica in the Southern Ocean along $170^{\circ}$ W. Deep Sea Res. Part II Top. Stud. Oceanogr. 48, 4275-4297. doi: 10.1016/s0967-0645(01)00089-3

Buesseler, K. O., Benitez-Nelson, C. R., Moran, S. B., Burd, A., Charette, M., Cochran, J. K., et al. (2006). An assessment of particulate organic carbon to thorium-234 ratios in the ocean and their impact on the application of ${ }^{234} \mathrm{Th}$ as a POC flux proxy. Mar. Chem. 100, 213-233. doi: 10.1016/j.marchem.2005.10. 013

Buesseler, K. O., Jayne, S. R., Fisher, N. S., Rypina, I. I., Baumann, H., Baumann, Z., et al. (2012). Fukushima-derived radionuclides in the ocean and biota off Japan. Proc. Natl. Acad. Sci. U.S.A. 109, 5984-5988. doi: 10.1073/pnas.1120794109

Cao, R., Liu, Y., Wang, Q., Dong, Z., Yang, D., Liu, H., et al. (2018). Seawater acidification aggravated cadmium toxicity in the oyster Crassostrea gigas: metal bioaccumulation, subcellular distribution and multiple physiological responses. Sci. Total Environ. 642, 809-823. doi: 10.1016/j.scitotenv.2018.06.126

Cappello, T., Brandão, F., Guilherme, S., Santos, M. A., Maisano, M., Mauceri, A., et al. (2016). Insights into the mechanisms underlying mercury-induced oxidative stress in gills of wild fish (Liza aurata) combining 1H NMR metabolomics and conventional biochemical assays. Sci. Total Environ. 548549, 13-24. doi: 10.1016/j.scitotenv.2016.01.008

Casado-Martinez, M. C., Smith, B. D., DelValls, T. A., and Rainbow, P. S. (2009). Pathways of trace metal uptake in the lugworm Arenicola marina. Aquat. Toxicol. 92, 9-17. doi: 10.1016/j.aquatox.2008.12.010

Charette, M. A. (2001). Utility of radium isotopes for evaluating the input and transport of groundwater-derived nitrogen to a Cape Cod estuary. Limnol Oceanogr. 46, 465-470. doi: 10.4319/lo.2001.46.2.0465

Chen, M., Ma, Q., Guo, L., Qiu, Y., Li, Y., and Yang, W. (2012). Importance of lateral transport processes to ${ }^{210} \mathrm{~Pb}$ budget in the eastern Chukchi Sea during summer 2003. Deep Sea Res. Part II Top. Stud. Oceanogr. 8, 53-62. doi: 10.1016/ j.dsr2.2012.03.011

Cherry, R. D., and Heyraud, M. (1981). Polonium-210 content of marine shrimp: variation with biological and environmental factors. Mar. Biol. 65, 165-175. doi: $10.1007 / \mathrm{bf} 00397082$

Cherry, R. D., and Heyraud, M. (1982). Evidence of high natural radiation doses in certain mid-water oceanic organisms. Science 218, 54-56. doi: 10.1126/science. 7123217

Close, H. G. (2019). Compound-specific isotope geochemistry in the ocean. Annu. Rev. Mar. Sci. 11, 27-56. doi: 10.1146/annurev-marine-121916-063634

Cresswell, T., Mazumder, D., Callaghan, P. D., Nguyen, A., Corry, M., and Simpson, S. L. (2017a). Metal transfer among organs following short- and long-term exposures using autoradiography: cadmium bioaccumulation by the freshwater prawn Macrobrachium australiense. Environ. Sci. Technol. 51, 4054-4060. doi: 10.1021/acs.est.6b06471
Cresswell, T., Metian, M., Golding, L. A., and Wood, M. D. (2017b). Aquatic live animal radiotracing studies for ecotoxicological applications: addressing fundamental methodological deficiencies. J. Environ. Radioact. 17, 435-460. doi: 10.1016/j.jenvrad.2017.05.017

Cresswell, T., Simpson, S. L., Mazumder, D., Callaghan, P. D., and Nguyen, A. P. (2015). Bioaccumulation kinetics and organ distribution of cadmium and zinc in the freshwater decapod crustacean Macrobrachium australiense. Environ. Sci. Technol. 49, 1182-1189. doi: 10.1021/es505254w

Cresswell, T., Simpson, S. L., Smith, R. E. W., Nugegoda, D., Mazumder, D., and Twining, J. (2014). Bioaccumulation and retention kinetics of cadmium in the freshwater decapod Macrobrachium australiense. Aquat. Toxicol. 148, 174-183. doi: 10.1016/j.aquatox.2014.01.006

Cuellar-Martinez, T., Ruiz-Fernández, A. C., Alonso-Hernández, C., AmayaMonterrosa, O., Quintanilla, R., Carrillo-Ovalle, H. L., et al. (2018). Addressing the problem of harmful algal blooms in Latin America and the CaribbeanA regional network for early warning and response. Front. Mar. Sci. 5:409. doi: 10.3389/fmars.2018.00409

Dahlgaard, H. (1986). Effects of season and temperature on long-term in situ loss rates of $\mathrm{Pu}, \mathrm{Am}, \mathrm{Np}, \mathrm{Eu}, \mathrm{Ce}, \mathrm{Ag}, \mathrm{Tc}, \mathrm{Zn}, \mathrm{Co}$ and $\mathrm{Mn}$ in a Baltic Mytilus edulis population. Mar. Ecol. Prog. Ser. 33, 157-165. doi: 10.3354/meps033157

Danis, B., Bustamante, P., Cotret, O., Teyssie, J. L., Fowler, S. W., and Warnau, M. (2005). Bioaccumulation of PCBs in the cuttlefish Sepia officinalis from seawater, sediment and food pathways. Environ. Pollut. 134, 113-122. doi: 10.1016/j.envpol.2004.07.010

de Paiva Magalhães, D., da Costa Marques, M., Baptista, D., and Buss, D. (2015). Metal bioavailability and toxicity in freshwaters. Environ. Chem. Lett. 13, 69-87. doi: 10.1007/s10311-015-0491-9

Dutton, J., and Fisher, N. S. (2014). Modeling metal bioaccumulation and tissue distribution in killifish (Fundulus heteroclitus) in three contaminated estuaries. Environ. Toxicol. Chem. 33, 89-101. doi: 10.1002/etc.2392

Dwight, R. H., Fernandez, L. M., Baker, D. B., Semenza, J. C., and Olson, B. H. (2005). Estimating the economic burden from illnesses associated with recreational coastal water pollution-a case study in Orange County, California. J. Environ. Manage. 76, 95-103. doi: 10.1016/j.jenvman.2004.11.017

European Commission (1990). "The Radiation Exposure of the Population of the European Community from Radioactivity in Norther Europe Marine Waters Project 'Marina', RP47, EUR 12483".). Brussels: European Commission.

Evans, T. W., Coffinet, S., Könneke, M., Lipp, J. S., Becker, K. W., Elvert, M., et al. (2019). Assessing the carbon assimilation and production of benthic archaeal lipid biomarkers using lipid-RIP. Geochim. Cosmochim. Acta 265, 431-442. doi: 10.1016/j.gca.2019.08.030

Evans, T. W., Könneke, M., Lipp, J. S., Adhikari, R. R., Taubner, H., Elvert, M., et al. (2018). Lipid biosynthesis of Nitrosopumilus maritimus dissected by lipid specific radioisotope probing (lipid-RIP) under contrasting ammonium supply. Geochim. Cosmochim. Acta 242, 51-63. doi: 10.1016/j.gca.2018.09.001

Fisher, N. S., Beaugelin-Seiller, K., Hinton, T. G., Baumann, Z., Madigan, D. J., and Garnier-Laplace, J. (2013). Evaluation of radiation doses and associated risk from the Fukushima nuclear accident to marine biota and human consumers of seafood. Proc. Natl. Acad. Sci. U.S.A. 110, 10670-10675. doi: 10.1073/pnas. 1221834110

Fisher, N. S., Burns, K. A., Cherry, R. D., and Heyraud, M. (1983). Accumulation and cellular distribution of ${ }^{241} \mathrm{Am},{ }^{210} \mathrm{Po}$ and ${ }^{210} \mathrm{~Pb}$ in two marine algae. Mar. Ecol. Prog. Ser. 11, 233-237. doi: 10.3354/meps011233

Fisher, N. S., Cochran, J. K., Krishnaswami, S., and Livingston, H. D. (1988). Predicting the oceanic flux of radionuclides on sinking biogenic debris. Nature 335, 622-625. doi: 10.1038/335622a0

Fisher, N. S., Fowler, S. W., and Madigan, D. J. (2015). Perspectives and reflections on the public reaction to recent Fukushima-related radionuclide studies and a call for enhanced training in environmental radioactivity. Environ. Toxicol. Chem. 34, 707-709. doi: 10.1002/etc.2860

Fisher, N. S., and Reinfelder, J. R. (1995). "The trophic transfer of metals in marine systems," in Metal Speciation and Bioavailability in Aquatic Systems, eds A. Tessier and D. R. Turner (Chichester: John Wiley \& Sons), 363-406.

Fisher, N. S., Stupakoff, I., Sañudo-Wilhelmy, S., Wang, W.-X., Teyssié, J.-L., Fowler, S. W., et al. (2000). Trace metals in marine copepods: a field test of a bioaccumulation model coupled to laboratory uptake kinetics data. Mar. Ecol. Prog. Ser. 194, 211-218. doi: 10.3354/meps194211

Fisher, N. S., Teyssie, J. L., Fowler, S. W., and Wang, W. X. (1996). Accumulation and retention of metals in mussels from food and water: a comparison under 
field and laboratory conditions. Environ. Sci. Technol. 30, 3232-3242. doi: $10.1021 /$ es 960009 u

Fowler, S. W. (2011). ${ }^{210}$ Po in the marine environment with emphasis on its behaviour within the biosphere. J. Environ. Radioact. 102, 448-461. doi: 10. 1016/j.jenvrad.2010.10.008

Fowler, S. W., and Fisher, N. S. (2005). "Chapter 6 Radionuclides in the biosphere," in Radioactivity in the Environment, ed. H. D. Livingston (Amsterdam: Elsevier), 167-203. doi: 10.1016/s1569-4860(05)80007-5

Fowler, S. W., Teyssie, J. L., Cotret, O., Danis, B., Rouleau, C., and Warnau, M. (2004). Applied radiotracer techniques for studying pollutant bioaccumulation in selected marine organisms (jellyfish, crabs and sea stars). Nukleonika 49, $97-100$

Fry, B. (2006). Stable Isotope Ecology. New York, NY: Springer-Verlag.

Fuhrman, J. A., and Azam, F. (1980). Bacterioplankton secondary production estimates for coastal waters of British Columbia, Antarctica, and California. Appl. Environ. Microbiol. 39, 1085-1095. doi: 10.1128/aem.39.6.1085-1095. 1980

Garcia-Leon, M. (2018). Accelerator Mass Spectrometry (AMS) in Radioecology. J Environ Radioact 186, 116-123. doi: 10.1016/j.jenvrad.2017.06.023

Gosner, K. (1960). A simplified table for staging anuran embryos and larvae with notes on identification. Herpetologica 16, 183-190. doi: 10.2307/3890061

Götze, S., Bock, C., Eymann, C., Lannig, G., Steffen, J. B. M., and Pörtner, H.-O. (2020). Single and combined effects of the "Deadly trio" hypoxia, hypercapnia and warming on the cellular metabolism of the great scallop Pecten maximus. Comp. Biochem. Physiol. Part B Biochem. Mol. Biol. 243-244:110438. doi: 10. 1016/j.cbpb.2020.110438

Hallegraeff, G. M. (2010). Ocean climate change, phytoplankton community responses, and harmful algal blooms: a formidable predictive challenge. J. Phycol. 46, 220-235. doi: 10.1111/j.1529-8817.2010.00815.x

Harmelin-Vivien, M., Bodiguel, X., Charmasson, S., Loizeau, V., Mellon-Duval, C., Tronczyński, J., et al. (2012). Differential biomagnification of PCB, PBDE, $\mathrm{Hg}$ and radiocesium in the food web of the European hake from the NW Mediterranean. Mar. Pollut. Bull. 64, 974-983. doi: 10.1016/j.marpolbul.2012. 02.014

Heisler, J., Glibert, P. M., Burkholder, J. M., Anderson, D. M., Cochlan, W., Dennison, W. C., et al. (2008). Eutrophication and harmful algal blooms: a scientific consensus. Harmful Algae 8, 3-13. doi: 10.1016/j.hal.2008.08.006

Heyraud, M., and Cherry, R. D. (1979). Polonium-210 and lead-210 in marine food chains. Mar. Biol. 52, 227-236. doi: 10.1007/bf00398136

Huo, D., Sun, L., Ru, X., Zhang, L., Lin, C., Liu, S., et al. (2018). Impact of hypoxia stress on the physiological responses of sea cucumber Apostichopus japonicus: respiration, digestion, immunity and oxidative damage. PeerJ 6:e4651. doi: 10.7717/peerj.4651

Hutchins, D. A., DiTullio, G. R., and Burland, K. W. (1993). Iron and regenerated production: evidence for biological iron recycling in two marine environments. Limnol. Oceanogr. 38, 1242-1255. doi: 10.4319/lo.1993.38.6.1242

IAEA (2004). Sediment Distribution Coefficients and Concentration Factors for Biota in the Marine Environment, Technical Report Series No. 422. Vienna: International Atomic Energy Agency.

IAEA (2010). Nuclear and Isotopic Techniques for the Characterization of Submarine Groundwater Discharge in Coastal Zones. Vienna: International Atomic Energy Agency.

IAEA (2013). Detection of Harmful Algal Toxins Using the Radioligand Receptor Binding Assay: A Manual of Methods (TECFOC-1729). Vienna: International Atomic Energy Agency.

ICRP (2008). Environmental Protection - the Concept and Use of Reference Animals and Plants. ICRP Publication 108. Ann. ICRP 38, 1-242.

Jambeck, J. R., Geyer, R., Wilcox, C., Siegler, T. R., Perryman, M., Andrady, A., et al. (2015). Plastic waste inputs from land into the ocean. Science 347, 768-771. doi: $10.1126 /$ science. 1260352

Jeffree, R. A., Oberhansli, F., Teyssie, J.-L., and Fowler, S. W. (2015). Maternal transfer of anthropogenic radionuclides to eggs in a small shark. J. Environ. Radioact. 147, 43-50. doi: 10.1016/j.jenvrad.2015.05.009

Johansen, M. P., Child, D. P., Cresswell, T., Harrison, J. J., Hotchkis, M. A. C., Howell, N. R., et al. (2019a). Plutonium and other radionuclides persist across marine-to-terrestrial ecotopes in the Montebello Islands sixty years after nuclear tests. Sci. Total Environ. 691, 572-583. doi: 10.1016/j.scitotenv.2019. 06.531
Johansen, M. P., Cresswell, T., Davis, J., Howard, D. L., Howell, N., and Prentice, E. (2019b). Biofilm-enhanced adsorption of strong and weak cations onto different microplastic sample types: use of spectroscopy, microscopy and radiotracer methods. Water Res. 158, 392-400. doi: 10.1016/j.watres.2019.04.029

Jones, P., Maiti, K., and McManus, J. (2015). Lead-210 and Polonium-210 disequilibria in the northern Gulf of Mexico hypoxic zone. Mar. Chem. 169, 1-15. doi: 10.1016/j.marchem.2014.12.007

Jørgensen, B. B., and Fenchel, T. (1974). The sulfur cycle of a marine sediment model system. Mar. Biol. 24, 189-201. doi: 10.1007/bf00391893

Kessouri, F., Ulses, C., Estournel, C., Marsaleix, P., Severin, T., Pujo-Pay, M., et al. (2017). Nitrogen and phosphorus budgets in the northwestern mediterranean deep convection region. J. Geophys. Res. Oceans 122, 9429-9454. doi: 10.1002/ 2016jc012665

Kirchman, D., K'Nees, E., and Hodson, R. (1985). Leucine incorporation and its potential as a measure of protein synthesis by bacteria in natural aquatic systems. Appl. Environ. Microbiol. 49, 599-607. doi: 10.1128/aem.49.3.599-607. 1985

Kudela, R. M., Seeyave, S., and Cochlan, W. P. (2010). The role of nutrients in regulation and promotion of harmful algal blooms in upwelling systems. Prog. Oceanogr. 85, 122-135. doi: 10.1016/j.pocean.2010.02.008

Lacoue-Labarthe, T., Warnau, M., Oberhänsli, F., Teyssié, J.-L., Jeffree, R., and Bustamante, P. (2008). First experiments on the maternal transfer of metals in the cuttlefish Sepia officinalis. Mar. Pollut. Bull. 57, 826-831. doi: 10.1016/ j.marpolbul.2008.01.042

Lam, I. K. S., and Wang, W.-X. (2006). Transgenerational retention and maternal transfer of selenium in Daphnia magna. Environ. Toxicol. Chem. 25, 2519-2525. doi: 10.1897/05-631r.1

Lanctôt, C. M., Cresswell, T., Callaghan, P. D., and Melvin, S. D. (2017). Bioaccumulation and biodistribution of selenium in metamorphosing tadpoles. Environ. Sci. Technol. 51, 5764-5773. doi: 10.1021/acs.est.7b00300

Lankadurai, B. P., Nagato, E. G., and Simpson, M. J. (2013). Environmental metabolomics: an emerging approach to study organism responses to environmental stressors. Environ. Rev. 21, 180-205. doi: 10.1139/er-2013-0011

Lannig, G., Eilers, S., Pörtner, H. O., Sokolova, I. M., and Bock, C. (2010). Impact of ocean acidification on energy metabolism of oyster, Crassostrea gigas-changes in metabolic pathways and thermal response. Mar. Drugs 8, 2318-2339. doi: $10.3390 / \mathrm{md} 8082318$

Lauterbur, P. C., Foster, M. A., Williams, R. J. P., Andrew, E. R., and Radda, G. K. (1980). Progress in n.m.r. zeugmatographic imaging. Philos. Trans. R. Soc. Lond. B Biol. Sci. 289, 483-487. doi: 10.1098/rstb.1980.0066

Lee, C.-S., and Fisher, N. S. (2016). Methylmercury uptake by diverse marine phytoplankton. Limnol. Oceanogr. 61, 1626-1639. doi: 10.1002/lno.10318

Lee, C.-S., and Fisher, N. S. (2017). Bioaccumulation of methylmercury in a marine copepod. Environ. Toxicol. Chem. 36, 1287-1293. doi: 10.1002/etc.3660

Li, W., Joshi, S. R., Hou, G., Burdige, D. J., Sparks, D. L., and Jaisi, D. P. (2015). Characterizing phosphorus speciation of chesapeake bay sediments using chemical extraction, ${ }^{31} \mathrm{PNMR}$, and $\mathrm{X}$-ray absorption fine structure spectroscopy. Environ. Sci. Technol. 49, 203-211. doi: 10.1021/es504648d

López-Lora, M., and Chamizo, E. (2019). Accelerator mass spectrometry of ${ }^{237} \mathrm{~Np},{ }^{239} \mathrm{Pu}$ and ${ }^{240} \mathrm{Pu}$ for environmental studies at the Centro Nacional de Aceleradores. Nucl. Instrum. Methods Phys. Res. Sect. B Beam Interact. Mater. Atoms 455, 39-51. doi: 10.1016/j.nimb.2019.06.018

Louis, J., Pedrotti, M. L., Gazeau, F., and Guieu, C. (2017). Experimental evidence of formation of transparent exopolymer particles (TEP) and POC export provoked by dust addition under current and high $\mathrm{pCO} 2$ conditions. PLoS One 12:e171980. doi: 10.1371/journal.pone.0171980

Luoma, S. N. (1989). Can we determine the biological availability of sedimentbound trace elements? Hydrobiologia 176, 379-396. doi: 10.1007/BF00026572

Luoma, S. N., and Rainbow, P. S. (2005). Why is metal bioaccumulation so variable? Biodynamics as a unifying concept. Environ. Sci. Technol. 39, 1921-1931. doi: $10.1021 / \mathrm{es} 048947 \mathrm{e}$

Luoma, S. N., and Rainbow, P. S. (2008). Metal Contamination in Aquatic Environments: Science and Lateral Management. Cambridge: Cambridge University Press.

Maiti, K., Bosu, S., D'Sa, E. J., Adhikari, P. L., Sutor, M., and Longnecker, K. (2016). Export fluxes in northern Gulf of Mexico - Comparative evaluation of direct, indirect and satellite-based estimates. Mar. Chem. 184, 60-77. doi: 10.1016/j.marchem.2016.06.001 
Maldonado, M. T., Hughes, M. P., Rue, E. L., and Wells, M. L. (2002). The effect of $\mathrm{Fe}$ and $\mathrm{Cu}$ on growth and domoic acid production by Pseudo-nitzschia multiseries and Pseudo-nitzschia australis. Limnol. Oceanogr. 47, 515-526. doi: 10.4319/lo.2002.47.2.0515

Mari, X., Rochelle-Newall, E., Torréton, J.-P., Pringault, O., Bettarel, Y., Motegi, C., et al. (2012). Production of individual marine organic aggregates using Paramagnetic Microspheres: a new tool for examining microbial associations with aggregates. Limnol. Oceanogr. Methods 10, 155-166. doi: 10.4319/lom. 2012.10.155

Mathews, T., and Fisher, N. S. (2008). Evaluating the trophic transfer of cadmium, polonium, and methylmercury in an estuarine food chain. Environ. Toxicol. Chem. 27, 1093-1101. doi: 10.1897/07-318.1

Mathews, T., and Fisher, N. S. (2009). Dominance of dietary intake of metals in marine elasmobranch and teleost fish. Sci. Total Environ. 407, 5156-5161. doi: 10.1016/j.scitotenv.2009.06.003

Mato, Y., Isobe, T., Takada, H., Kanehiro, H., Ohtake, C., and Kaminuma, T. (2001). Plastic resin pellets as a transport medium for toxic chemicals in the marine environment. Environ. Sci. Technol. 35, 318-324. doi: 10.1021/es0010498

Matsumoto, K. (2007). Radiocarbon-based circulation age of the world oceans. J. Geophys. Res. Oceans 112:C09004. doi: 10.1029/2007jc004095

Matsumoto, K., and Key, R. (2004). "Natural radiocarbon distribution in the deep ocean," in Global Environmental Change in the Ocean and on Land, eds M. Shiyomi, H. Kawahata, H. Koizumi, A. Tsuda, and Y. Awaya (Tokyo: TERRAPUB), 45-58.

McNichol, A. P., and Aluwihare, L. I. (2007). The power of radiocarbon in biogeochemical studies of the marine carbon cycle: insights from studies of dissolved and particulate organic carbon (DOC and POC). Chem. Rev. 107, 443-466. doi: 10.1021/cr050374g

McNichol, A. P., Schneider, R. J., von Reden, K. F., Gagnon, A. R., Elder, K. L., NOSAMS et al. (2000). Ten years after - The WOCE AMS radiocarbon program. Nucl. Instrum. Methods Phys. Res. Sect. B Beam Interact. Mater. Atoms 172, 479-484. doi: 10.1016/s0168-583x(00)00093-8

Metian, M., Hédouin, L., Eltayeb, M. M., Lacoue-Labarthe, T., Teyssié, J.-L., Mugnier, C., et al. (2010). Metal and metalloid bioaccumulation in the Pacific blue shrimp Litopenaeus stylirostris (Stimpson) from New Caledonia: laboratory and field studies. Mar. Pollut. Bull. 61, 576-584. doi: 10.1016/j.marpolbul.2010. 06.035

Metian, M., Pouil, S., and Fowler, S. W. (2019a). Radiocesium accumulation in aquatic organisms: a global synthesis from an experimentalist's perspective. J. Environ. Radioact. 198, 147-158. doi: 10.1016/j.jenvrad.2018. 11.013

Metian, M., Pouil, S., Hédouin, L., Oberhänsli, F., Teyssié, J.-L., Bustamante, P., et al. (2016). Differential bioaccumulation of (134)Cs in tropical marine organisms and the relative importance of exposure pathways. J. Environ. Radioact. 152, 127-135. doi: 10.1016/j.jenvrad.2015.11.012

Metian, M., Renaud, F., Oberhänsli, F., Teyssié, J.-L., Temara, A., and Warnau, M. (2019b). Biokinetics of the anionic surfactant linear alkylbenzene sulfonate (LAS) in the marine fish Sparus aurata: investigation via seawater and food exposure pathways. Aquat. Toxicol. 216:105316. doi: 10.1016/j.aquatox.2019. 105316

Moffett, J. W., and German, C. R. (2018). The U.S.GEOTRACES Eastern Tropical Pacific Transect (GP16). Mar. Chem. 201, 1-5. doi: 10.1016/j.marchem.2017. 12.001

Moore, W. S. (2006). The role of submarine groundwater discharge in coastal biogeochemistry. J. Geochem. Explor. 88, 389-393. doi: 10.1016/j.gexplo.2005. 08.082

Morel, F. M. M., Kraepiel, A. M. L., and Amyot, M. (1998). The chemical cycle and bioaccumulation of mercury. Annu. Rev. Ecol. Syst. 29, 543-566. doi: 10.1146/ annurev.ecolsys.29.1.543

Mouestrup, Ø., Akselmann, R., Fraga, S., Hoppenarth, M., Iwataki, M., Komarek, J., et al. (2009). IOC-UNESCO Taxonomic Reference List of Harmful Micro Algae. Available online at: www.marinespecies.org/hab (accessed November 20, 2019).

Munier, B., and Bendell, L. I. (2018). Macro and micro plastics sorb and desorb metals and act as a point source of trace metals to coastal ecosystems. PLoS One 13:e0191759. doi: 10.1371/journal.pone.0191759

Murray, J. W., Paul, B., Dunne, J. P., and Chapin, T. (2005). 234Th, 210Pb, $210 \mathrm{Po}$ and stable $\mathrm{Pb}$ in the central equatorial Pacific: tracers for particle cycling. Deep
Sea Res. Part I Oceanogr. Res. Pap. 52, 2109-2139. doi: 10.1016/j.dsr.2005. 06.016

Nielsen, E. S. (1952). The use of radio-active carbon (C14) for measuring organic production in the sea. ICES J. Mar. Sci. 18, 117-140. doi: 10.1093/icesjms/18. 2.117

Nozaki, Y., Dobashi, F., Kato, Y., and Yamamoto, Y. (1998). Distribution of Ra isotopes and the ${ }^{210} \mathrm{~Pb}$ and ${ }^{210} \mathrm{Po}$ balance in surface seawaters of the mid Northern Hemisphere. Deep Sea Res. Part I Oceanogr. Res. Pap. 45, 1263-1284. doi: 10.1016/s0967-0637(98)00016-8

O’Mara, K., Adams, M., Burford, M. A., Fry, B., and Cresswell, T. (2019). Uptake and accumulation of cadmium, manganese and zinc by fisheries species: trophic differences in sensitivity to environmental metal accumulation. Sci. Total Environ. 690, 867-877. doi: 10.1016/j.scitotenv.2019.07.016

Ouverney, C. C., and Fuhrman, J. A. (1999). Combined microautoradiography16S rRNA probe technique for determination of radioisotope uptake by specific microbial cell types in situ. Appl. Environ. Microbiol. 65, 1746-1752. doi: 10.1128/aem.65.4.1746-1752.1999

Patterson, C., Tilton, G., and Inghram, M. (1955). Age of the Earth. Science 121, 69-75. doi: 10.1126/science.121.3134.69

Payne, T. E., Hatje, V., Itakura, T., McOrist, G. D., and Russell, R. (2004). Radionuclide applications in laboratory studies of environmental surface reactions. J. Environ. Radioact. 76, 237-251. doi: 10.1016/j.jenvrad.2004.03.029

Peck, K. A., Lomax, D. P., Olson, O. P., Sol, S. Y., Swanson, P., and Johnson, L. L. (2011). Development of an enzyme-linked immunosorbent assay for quantifying vitellogenin in Pacific salmon and assessment of field exposure to environmental estrogens. Environ. Toxicol. Chem. 30, 477-486. doi: 10.1002/ etc. 390

Perry, M. J. (1976). Phosphate utilization by an oceanic diatom in phosphoruslimited chemostat culture and in the oligotrophic waters of the central North Pacific. Limnol. Oceanogr. 21, 88-107. doi: 10.4319/lo.1976.21.1.0088

Povinec, P. P. (2017). Analysis of radionuclides at ultra-low levels: a comparison of low and high-energy mass spectrometry with gamma-spectrometry for radiopurity measurements. Appl. Radiat. Isotopes 126, 26-30. doi: 10.1016/j. apradiso.2017.01.029

Rachold, V., Eicken, H., Gordeev, V. V., Grigoriev, M. N., Hubberten, H.-W., Lisitzin, A. P., et al. (2004). "Modern Terrigenous organic carbon input to the arctic ocean," in The Organic Carbon Cycle in the Arctic Ocean, eds R. Stein and R. W. MacDonald (Berlin: Springer), 33-55. doi: 10.1007/978-3-642-18912-8_2 Reinfelder, J. R., Fisher, N. S., Luoma, S. N., Nichols, J. W., and Wang, W. X. (1998). Trace element trophic transfer in aquatic organisms: a critique of the kinetic model approach. Sci. Total Environ. 219, 117-135. doi: 10.1016/S0048-9697(98) 00225-3

Renaud, F., Warnau, M., Oberhänsli, F., Teyssié, J.-L., Temara, A., Rouleau, C., et al. (2014). Bioconcentration of the anionic surfactant linear alkylbenzene sulfonate (LAS) in the marine shrimp Palaemonetes varians: a radiotracer study. Mar. Pollut. Bull. 85, 244-247. doi: 10.1016/j.marpolbul.2014.06.023

Revelle, R., and Suess, H. E. (1957). Carbon dioxide exchange between atmosphere and ocean and the question of an increase of atmospheric $\mathrm{CO}_{2}$ during the past decades. Tellus 9, 18-27. doi: 10.1111/j.2153-3490.1957.tb01849.x

Robbins, J. A., and Edgington, D. N. (1975). Determination of recent sedimentation rates in Lake Michigan using Pb-210 and Cs-137. Geochim. Cosmochim. Acta 39, 285-304. doi: 10.1016/0016-7037(75)90198-2

Roberts, K. A., Xu, C., Hung, C.-C., Conte, M. H., and Santschi, P. H. (2009). Scavenging and fractionation of thorium vs. protactinium in the ocean, as determined from particle-water partitioning experiments with sediment trap material from the Gulf of Mexico and Sargasso Sea. Earth Planet. Sci. Lett. 286, 131-138. doi: 10.1016/j.epsl.2009.06.029

Roca-Martí, M., Puigcorbé, V., Iversen, M. H., van der Loeff, M. R., Klaas, C., Cheah, W., et al. (2017). High particulate organic carbon export during the decline of a vast diatom bloom in the Atlantic sector of the Southern Ocean. Deep Sea Res. Part II Top. Stud. Oceanogr. 138, 102-115. doi: 10.1016/j.dsr2. 2015.12.007

Rocha, C., Veiga-Pires, C., Scholten, J., Knoeller, K., Gröcke, D. R., Carvalho, L., et al. (2016). Assessing land-ocean connectivity via submarine groundwater discharge (SGD) in the Ria Formosa Lagoon (Portugal): combining radon measurements and stable isotope hydrology. Hydrol. Earth Syst. Sci. 20, $3077-$ 3098. doi: 10.5194/hess-20-3077-2016 
Roditi, H. A., Fisher, N. S., and Sañudo-Wilhelmy, S. A. (2000). Field testing a metal bioaccumulation model for zebra mussels. Environ. Sci. Technol. 34, 2817-2825. doi: 10.1021/es991442h

Romera-Castillo, C., Pinto, M., Langer, T. M., Álvarez-Salgado, X. A., and Herndl, G. J. (2018). Dissolved organic carbon leaching from plastics stimulates microbial activity in the ocean. Nat. Commun. 9:1430. doi: 10.1038/s41467-01803798-5

Roos, P. (2008). “Analysis of radionuclides using ICP-MS," in Radioactivity in the Environment, ed. P. P. Povinec (Amsterdam: Elsevier), 295-330. doi: 10.1016/ s1569-4860(07)11009-3

Russell, B. C., Croudace, I. W., and Warwick, P. E. (2015). Determination of ${ }^{135} \mathrm{Cs}$ and ${ }^{137} \mathrm{Cs}$ in environmental samples: a review. Anal. Chim. Acta 890, 7-20. doi: 10.1016/j.aca.2015.06.037

Schmidt, M., Windisch, H. S., Ludwichowski, K.-U., Seegert, S. L. L., Pörtner, H.-O., Storch, D., et al. (2017). Differences in neurochemical profiles of two gadid species under ocean warming and acidification. Front. Zool. 14:49. doi: 10.1186/s12983-017-0238-5

Schulz, K. G., Bach, L. T., Bellerby, R. G. J., Bermúdez, R., Büdenbender, J., Boxhammer, T., et al. (2017). Phytoplankton blooms at increasing levels of atmospheric carbon dioxide: experimental evidence for negative effects on prymnesiophytes and positive on small picoeukaryotes. Front. Mar. Sci. 4:64. doi: 10.3389/fmars.2017.00064

Shi, K., Hou, X., Roos, P., and Wu, W. (2012). Determination of technetium-99 in environmental samples: a review. Anal. Chim. Acta 709, 1-20. doi: 10.1016/j. aca.2011.10.020

Silver, M. W., Bargu, S., Coale, S. L., Benitez-Nelson, C. R., Garcia, A. C., Roberts, K. J., et al. (2010). Toxic diatoms and domoic acid in natural and iron enriched waters of the oceanic Pacific. Proc. Natl. Acad. Sci. U.S.A. 107, 20762-20767. doi: 10.1073/pnas.1006968107

Speers, A. E., Besedin, E. Y., Palardy, J. E., and Moore, C. (2016). Impacts of climate change and ocean acidification on coral reef fisheries: an integrated ecological-economic model. Ecol. Econ. 128, 33-43. doi: 10.1016/j.ecolecon. 2016.04.012

Stewart, G., Cochran, J. K., Miquel, J. C., Masqué, P., Szlosek, J., Rodriguez y Baena, A. M., et al. (2007). Comparing POC export from ${ }^{234} \mathrm{Th} /{ }^{238} \mathrm{U}$ and ${ }^{210} \mathrm{Po} /{ }^{210} \mathrm{~Pb}$ disequilibria with estimates from sediment traps in the northwest Mediterranean. Deep Sea Res. Part I Oceanogr. Res. Pap. 54, 1549-1570. doi: 10.1016/j.dsr.2007.06.005

Stewart, G., Fowler, S. W., and Fisher, N. S. (2008). "The bioaccumulation of Uand Th- series radionuclides in marine organisms," in U-Th Series Nuclides in Aquatic Systems, eds S. Krishnaswami and J. K. Cochran (Amsterdam: Elsevier Science), 269-305. doi: 10.1016/s1569-4860(07)00008-3

Stewart, G. M., and Fisher, N. S. (2003). Experimental studies on the accumulation of polonium-210 by marine phytoplankton. Limnol. Oceanogr. 48, 1193-1201. doi: $10.4319 /$ lo.2003.48.3.1193

Sunda, W. G. (2006). "Trace metals and harmful algal blooms," in Ecology of Harmful Algae, eds E. Granéli and J. T. Turner (Berlin: Springer), 203-214. doi: 10.1007/978-3-540-32210-8_16

Swart, P. K., Greer, L., Rosenheim, B. E., Moses, C. S., Waite, A. J., Winter, A., et al. (2010). The ${ }^{13} \mathrm{C}$ Suess effect in scleractinian corals mirror changes in the anthropogenic $\mathrm{CO}_{2}$ inventory of the surface oceans. Geophys. Res. Lett. 37:L05604. doi: 10.1029/2009gl041397

Swarzenski, P., and Porcelli, D. (2003). The behavior of U- and Th-series nuclides in groundwater. Rev. Mineral. Geochem. 52, 317-361. doi: 10.2113/0520317

Swarzenski, P. W. (2007). U/Th series radionuclides as coastal groundwater tracers. Chem. Rev. 107, 663-674. doi: 10.1021/cr0503761

Swarzenski, P. W., Baskaran, M., Rosenbauer, R. J., and Orem, W. H. (2006). Historical trace element distribution in sediments from the Mississippi River delta. Estuaries Coasts 29, 1094-1107. doi: 10.1007/bf02781812

Swarzenski, P. W., McKee, B. A., and Booth, J. G. (1995). Uranium geochemistry on the Amazon shelf: chemical phase partitioning and cycling across a salinity gradient. Geochim. Cosmochim. Acta 59, 7-18. doi: 10.1016/0016-7037(94) $00371-\mathrm{R}$

Tang, Y., and Stewart, G. (2019). The ${ }^{210} \mathrm{Po} /{ }^{210} \mathrm{~Pb}$ method to calculate particle export: lessons learned from the results of three GEOTRACES transects. Mar. Chem. 217:103692. doi: 10.1016/j.marchem.2019.103692

Tang, Y., Stewart, G., Lam, P. J., Rigaud, S., and Church, T. (2017). The influence of particle concentration and composition on the fractionation of ${ }^{210} \mathrm{Po}$ and ${ }^{210} \mathrm{~Pb}$ along the North Atlantic GEOTRACES transect GA03.
Deep Sea Res. Part I Oceanogr. Res. Pap. 128, 42-54. doi: 10.1016/j.dsr.2017. 09.001

Tikunov, A., Stoskopf, M., and Macdonald, J. (2014). Fluxomics of the eastern oyster for environmental stress studies. Metabolites 4, 53-70. doi: 10.3390/ metabo4010053

Trick, C. G., Bill, B. D., Cochlan, W. P., Wells, M. L., Trainer, V. L., and Pickell, L. D. (2010). Iron enrichment stimulates toxic diatom production in highnitrate, low-chlorophyll areas. Proc. Natl. Acad. Sci. U.S.A. 107, 5887-5892. doi: 10.1073/pnas.0910579107

Tripp-Valdez, M. A., Bock, C., Lucassen, M., Lluch-Cota, S. E., Sicard, M. T., Lannig, G., et al. (2017). Metabolic response and thermal tolerance of green abalone juveniles (Haliotis fulgens: Gastropoda) under acute hypoxia and hypercapnia. J. Exp. Mar. Biol. Ecol. 497, 11-18. doi: 10.1016/j.jembe.2017. 09.002

Turley, C., and Gattuso, J.-P. (2012). Future biological and ecosystem impacts of ocean acidification and their socioeconomic-policy implications. Curr. Opin. Environ. Sustain. 4, 278-286. doi: 10.1016/j.cosust.2012.05.007

van den Bergh, J. C. J. M., Nunes, P. A. L. D., Dotinga, H. M., Kooistra, W. H. C. F., Vrieling, E. G., and Peperzak, L. (2002). Exotic harmful algae in marine ecosystems: an integrated biological-economic-legal analysis of impacts and policies. Mar. Policy 26, 59-74. doi: 10.1016/S0308-597X(01)00032-X

Van Dolah, F. M., Fire, S. E., Leighfield, T. A., Mikulski, C. M., and Doucette, G. J. (2012). Determination of paralytic shellfish toxins in shellfish by receptor binding assay: collaborative study. J. AOAC Int. 95, 795-812. doi: 10.5740/ jaoacint.CS2011_27

Vestergren, J., Vincent, A. G., Jansson, M., Persson, P., Ilstedt, U., Gröbner, G., et al. (2012). High-resolution characterization of organic phosphorus in soil extracts using 2D ${ }^{1} \mathrm{H}_{-}{ }^{31} \mathrm{P}$ NMR correlation spectroscopy. Environ. Sci. Technol. 46, 3950-3956. doi: 10.1021/es204016h

Viant, M. R., Rosenblum, E. S., and Tjeerdema, R. S. (2003). NMRbased metabolomics: a powerful approach for characterizing the effects of environmental stressors on organism health. Environ. Sci. Technol. 37, 49824989. doi: 10.1021/es034281x

Wang, C., Baumann, Z., Madigan, D. J., and Fisher, N. S. (2016). Contaminated marine sediments as a source of cesium radioisotopes for benthic fauna near Fukushima. Environ. Sci. Technol. 50, 10448-10455. doi: 10.1021/acs.est. 6b02984

Wang, C., Cerrato, R. M., and Fisher, N. S. (2018). Temporal changes in (137)Cs concentrations in fish, sediments, and seawater off Fukushima Japan. Environ. Sci. Technol. 52, 13119-13126. doi: 10.1021/acs.est.8b03294

Wang, W.-X. (2011). Incorporating exposure into aquatic toxicological studies: an imperative. Aquat. Toxicol. 105(3-4, Suppl.), 9-15. doi: 10.1016/j.aquatox.2011. 05.016

Wang, W.-X., and Fisher, N. S. (1999). Delineating metal accumulation pathways for marine invertebrates. Sci. Total Environ. 237-238, 459-472. doi: 10.1016/ s0048-9697(99)00158-8

Wang, W. X., Fisher, N. S., and Luoma, S. N. (1996). Kinetic determinations of trace element bioaccumulation in the mussel Mytilus edulis. Mar. Ecol. Prog. Ser. 140, 91-113. doi: 10.3354/meps140091

Wang, W. X., Stupakoff, I., and Fisher, N. S. (1999). Bioavailability of dissolved and sediment-bound metals to a marine deposit-feeding polychaete. Mar. Ecol. Prog. Ser. 178, 281-293. doi: 10.3354/meps178281

Wang, X., and Wang, W.-X. (2006). Bioaccumulation and transfer of benzo(a)pyrene in a simplified marine food chain. Mar. Ecol. Prog. Ser. 312, 101-111. doi: 10.3354/meps312101

Wei, C. L., Lin, S. Y., Sheu, D. D. D., Chou, W. C., Yi, M. C., Santschi, P. H., et al. (2011). Particle-reactive radionuclides $\left({ }^{234} \mathrm{Th},{ }^{210} \mathrm{~Pb},{ }^{210} \mathrm{Po}\right)$ as tracers for the estimation of export production in the South China Sea. Biogeosciences 8, 3793-3808. doi: 10.5194/bg-8-3793-2011

Wells, M. L., Trainer, V. L., Smayda, T. J., Karlson, B. S. O., Trick, C. G., Kudela, R. M., et al. (2015). Harmful algal blooms and climate change: Learning from the past and present to forecast the future. Harmful Algae 49, 68-93. doi: 10.1016/j.hal.2015.07.009

Wells, M. L., Trick, C. G., Cochlan, W. P., Hughes, M. P., and Trainer, V. L. (2005). Domoic acid: the synergy of iron, copper, and the toxicity of diatoms. Limnol. Oceanogr. 50, 1908-1917. doi: 10.4319/lo.2005.50.6.1908

Wermter, F. C., Maus, B., Pörtner, H.-O., Dreher, W., and Bock, C. (2018). CO induced pHi changes in the brain of polar fish: a TauCEST application. NMR Biomed. 31:e3955. doi: 10.1002/nbm.3955 
White, S. L., and Rainbow, P. S. (1984). Regulation of zinc concentration by Palaemon elegans (Crustacea, Decapoda): zinc flux and effects of temperature, zinc concentration and moulting. Mar. Ecol. Prog. Ser. 16, 135-147. doi: 10. 3354/meps016135

White, S. L., and Rainbow, P. S. (1986). Accumulation of cadmium by Palaemon elegans (Crustacea, Decapoda). Mar. Ecol. Prog. Ser. 32, 17-25. doi: 10.3354/ meps032017

Willis, J. N., and Sunda, W. G. (1984). Relative contributions of food and water in the accumulation of zinc by two species of marine fish. Mar. Biol. 80, 273-279. doi: 10.1007/bf0039 2822

Yagi, N. (2016). "Impacts of the nuclear power plant accident and the start of trial operations in fukushima fisheries," in Agricultural Implications of the Fukushima Nuclear Accident: The First Three Years, eds T. M. Nakanishi and K. Tanoi (Tokyo: Springer Japan), 217-228. doi: 10.1007/978-4-431-558 28-6_17

Yarimizu, K., Cruz-López, R., and Carrano, C. J. (2018). Iron and harmful algae blooms: potential algal-bacterial mutualism between Lingulodinium polyedrum and Marinobacter algicola. Front. Mar. Sci. 5:180. doi: 10.3389/fmars.2018. 00180

Zheng, H., Yan, Z., Chen, J., Jin, H., Chen, C.-T. A., Liu, M., et al. (2018). Seasonal variations of dissolved organic matter in the East China Sea using EEMPARAFAC and implications for carbon and nutrient cycling. Sustainability 10:1444. doi: 10.3390/su10051444

Conflict of Interest: The authors declare that the research was conducted in the absence of any commercial or financial relationships that could be construed as a potential conflict of interest.

Copyright (c) 2020 Cresswell, Metian, Fisher, Charmasson, Hansman, Bam, Bock and Swarzenski. This is an open-access article distributed under the terms of the Creative Commons Attribution License (CC BY). The use, distribution or reproduction in other forums is permitted, provided the original author(s) and the copyright owner(s) are credited and that the original publication in this journal is cited, in accordance with accepted academic practice. No use, distribution or reproduction is permitted which does not comply with these terms. 